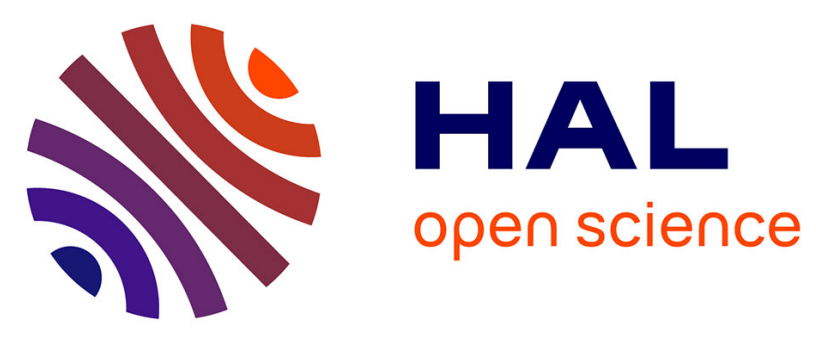

\title{
Rubisco: A promising plant protein to enrich wheat-based food without impairing dough viscoelasticity and protein polymerisation
}

Maude Ducrocq, Adeline Boire, Marc Anton, Valérie Micard, Marie-Hélène Morel

\section{To cite this version:}

Maude Ducrocq, Adeline Boire, Marc Anton, Valérie Micard, Marie-Hélène Morel. Rubisco: A promising plant protein to enrich wheat-based food without impairing dough viscoelasticity and protein polymerisation. Food Hydrocolloids, 2020, 109, 10.1016/j.foodhyd.2020.106101 . hal-03342600

\section{HAL Id: hal-03342600 https://hal.science/hal-03342600}

Submitted on 16 Nov 2021

HAL is a multi-disciplinary open access archive for the deposit and dissemination of scientific research documents, whether they are published or not. The documents may come from teaching and research institutions in France or abroad, or from public or private research centers.
L'archive ouverte pluridisciplinaire $\mathbf{H A L}$, est destinée au dépôt et à la diffusion de documents scientifiques de niveau recherche, publiés ou non, émanant des établissements d'enseignement et de recherche français ou étrangers, des laboratoires publics ou privés. 


\title{
Rubisco: a promising plant protein to enrich wheat-based food without impairing dough viscoelasticity and protein polymerization
}

\author{
Maude Ducrocq ${ }^{1,2}$, Adeline Boire ${ }^{2,}{ }^{*}$, Marc Anton ${ }^{2}$, Valérie Micard ${ }^{1}$, Marie-Hélène Morel ${ }^{1}$ \\ ${ }^{1}$ Univ. Montpellier, CIRAD, INRAE, SupAgro, UMR IATE, Bat. 31, 2 place Pierre Viala, 34060 Montpellier Cedex 01, \\ France \\ 2 INRAE, UR1268 BIA, ISD, Rue Yvette Cauchois, 44316 Nantes Cedex 03, France \\ *Corresponding author, e-mail address: adeline.boire@inrae.fr
}

\section{Highlights:}

- Rubisco addition does not decrease dough stiffening during heat treatment

- Rubisco forms both weak and covalent bonds during dough hydration and mixing

- Rubisco is part of the water-insoluble protein network

- In heat-treated dough, rubisco increases the concentration of large polymers

\begin{abstract}
:
Rubisco (ribulose-1,5-bisphosphate carboxylase/oxygenase), a leaf protein, has an interesting amino acid profile and promising functional properties. Incorporated in wheat-based products, it would increase their protein content and improve their essential amino acid profile, particularly lysine. The impact of rubisco enrichment on wheat dough mechanical properties and protein-protein interactions was investigated using Dynamic Mechanical Thermal Analysis and Size-Exclusion chromatography, respectively. Experiments were also performed on gluten and pea protein enriched doughs as a comparison. Wheat doughs with increasing concentrations of rubisco, gluten or pea proteins (from 0 to $33 \%$ of total proteins) were prepared using a $2 \mathrm{~g}$-mixograph at constant hydration. In contrast to pea proteins and gluten, rubisco does not reduce dough stiffening during heating, probably due to its own reactivity to temperature and to low competition with starch for water. Detailed analysis of protein interactions showed that rubisco is part of the gluten network formed during dough mixing through the establishment of weak and disulphide bonds. In addition, rubisco subunits form new covalent bonds during the heat treatment thereby increasing the concentration of SDS insoluble high molecular weight aggregates. These results suggest that rubisco actively participates in the formation of the dough protein network. The colocation of gluten and rubisco proteins on micrographs supports the hypothesis that they form a co-protein network.
\end{abstract}

Keywords: Rubisco; gluten; pea proteins; protein network; protein-protein interactions; dynamic mechanical thermal analysis (DMTA) 


\section{Introduction}

Foods of animal origin are a major source of proteins in today's Western diet. Nevertheless, their overconsumption raises public health (Friel et al., 2009) and environmental issues (Aiking, 2014; John Reynolds, David Buckley, Weinstein, \& Boland, 2014). A panel of experts recently underlined the need to shift to a diet richer in plant proteins (Willett et al., 2019). Among other things, this food transition requires the development of alternatives to meat proteins in Western countries. Development of meat analogues and dairy substitutes is part of the solution but there are still technological challenges to address to meet consumer preferences (Wild et al., 2014). Another strategy to meet nutritional needs is to enrich traditional food with plant proteins, leading to foods with higher protein content and a balanced amino acid profile. These enriched foods are currently mainly based on a combination of proteins from legumes and wheat (ING Economics department, 2017). The association of legumes with wheat counterbalances the lack of lysine or threonine in wheat proteins (Bahnassey, Khan, \& Harrold, 1986). However, adding legumes in wheat-based foods may impair the organoleptic quality of the product. As recently reviewed, fortifying durum wheat pasta with legumes increases cooking loss and reduces the cooked weight of pasta (Monnet, Laleg, Michon, \& Micard, 2019). This reflects higher leaching of solids from the pasta into the cooking water due to the weakening of the gluten network (Bahnassay \& Khan, 1986; Laleg et al., 2017). Weakening of the protein network is also responsible for the degradation of the textural properties of pasta enriched with legumes (Laleg et al., 2017; Petitot, Boyer, Minier, \& Micard, 2010). Similarly, the addition of legume proteins in bread dough affects the volume of the loaf by reducing its gas retention capacity as recently reviewed (Boukid, Zannini, Carini, \& Vittadini, 2019). The ability of wheat semolina or flour proteins to form a gluten matrix is the main factor influencing the strength and elastic properties of wheat dough that ensure the quality of wheat-based foods. However, the mechanisms through which extrinsic proteins affect the gluten network remain unclear. The addition of non-wheat components may dilute gluten proteins, thereby impairing and weakening the overall protein network (Laleg et al., 2017). It is therefore a challenge to develop protein-enriched wheat-based foods with minimized or even no gluten dilution effects.

Considerable attention has been paid to legume proteins for their nutritional quality and their availability. In the same way, leaf proteins have worthwhile nutritional qualities for human food (Gerloff, Lima, \& Stahmann, 1965; Lexander, Carlsson, Schalén, Simonsson, \& Lundborg, 1970). Leaf protein can be extracted from numerous crops, green by-products and aquatic plants (Ellis, 1979). The fractionation of wet green crops aims at recovering a juice with both high dry matter and protein content (Fiorentini \& Galoppini, 1983). The soluble part is mainly composed of ribulose-1,5-bisphosphate carboxylase/oxygenase (rubisco), an enzyme involved in carbon fixation, which is richer in sulphur-containing amino acids than wheat proteins, and also rich in lysine, threonine and tryptophan (Gerloff et al., 1965). Although several extraction processes have been described (R. H. Edwards et al., 1975; Knuckles, Bickoff, \& Kohler, 1972; Knuckles, De Fremery, Bickoff, \& Kohler, 1975), rubisco is still not used as an ingredient in human food because of the difficulty of extracting a functional white concentrate with no off-flavours. However, technological advances in extraction processes and recent studies on functionality are promoting the use of leaf protein concentrates as an ingredient in human food (Firdaous et al., 2017; Hadidi, Ibarz, Conde, \& Pagan, 2019; Kiskini, Vissers, Vincken, Gruppen, \& Wierenga, 2016; Martin, Castellani, de Jong, Bovetto, \& Schmitt, 2019; Tamayo Tenorio, Gieteling, De Jong, Boom, \& Van Der Goot, 2016; Udenigwe et al., 2017). Besides its nutritional interest, rubisco has been found to have interesting functional properties (Barbeau \& Kinsella, 1988; Douillard, 1985; Knuckles \& Kohler, 1982). Rubisco has a foaming capacity similar to egg white proteins (Sheen \& Sheen, 1985), good solubility at food pH and is able to form gels at low concentrations and low temperatures in aqueous buffers at several pH (Martin, Nieuwland, \& De Jong, 2014). The thermal denaturation and gelling properties of proteins are crucial to the structure and texture of wheat-based foods. To our knowledge, the functionality of rubisco when incorporated in a dense food matrix has not yet been studied.

The aim of this study was thus to investigate the impact of introducing rubisco on the structure of wheat protein. Micro wheat semolina doughs were used as a model food system to investigate the interactions between proteins and other components in protein-enriched wheat matrices. In addition to rubisco concentrate, the effects of adding gluten and pea protein were also studied as a comparison. Their impact on dough structuring during heating was studied using dynamic thermo-mechanical analysis (DMTA) at several enrichment rates ranging from 0 to $33 \%$ 
of total proteins. Protein polymerisation in doughs was studied by protein sequential extraction followed by sizeexclusion chromatography both before and after dough thermal treatment. The overall structure of the protein network was visualised by confocal scanning light microscopy (CSLM).

\section{Material and methods}

\subsection{Material}

Wheat semolina was provided by La Semoulerie de Bellevue (Panzani, Marseille, France) and passed through a 200 $\mu \mathrm{m}$ sieve before use. Pea protein concentrate (Nutralys, F85F) was purchased from Roquette (Lestrem, France) and rubisco concentrate was provided by Florette (Lessay, France). Rubisco was extracted from Cichorium endivia leaves using the extraction conditions of the WO 2014/104880 patent but excluding the hydrophobic column adsorption step. The gluten was extracted by hand from a durum wheat semolina dough based on Auger, Morel, Dewilde, \& Redl (2009) with some modifications. Briefly, doughs were prepared at $55 \%$ water content (wet basis). After a premixing step at $28 \mathrm{rpm}$ during $2.5 \mathrm{~min}$, the dough was mixed at $90 \mathrm{rpm}$ until optimum development time. The dough was then diluted and washed under demineralized water. Gluten was recovered on $800 \mu \mathrm{m}$ sieve and freeze-dried. To ensure constant moisture content, at least 14 days before the experiment, wheat semolina and protein concentrates were placed in a humidity-controlled chamber with a $\mathrm{K}_{2} \mathrm{CO}_{3}$ saturated salt solution at $20^{\circ} \mathrm{C}$ to maintain $43.16 \%$ relative humidity. The water content of powders was determined in triplicate by weighing after drying at $105^{\circ} \mathrm{C}$ for three hours. The protein content of all the raw materials was analysed using the Kjeldahl procedure (NF V 03-050, 1970) with a conversion factor of 5.7 for wheat semolina, pea proteins and gluten concentrates. A conversion factor of 5.8 was used for the rubisco concentrate based on the amino acid profile previously determined (data not shown). Analytical grade sodium dodecyl sulfate (SDS), sodium phosphate dibasic $\left(\mathrm{Na}_{2} \mathrm{HPO}_{4}\right)$ and monosodium phosphate $\left(\mathrm{NaH}_{2} \mathrm{PO}_{4}\right)$ were purchased from VWR international (Leuven, Belgium). Other chemicals were purchased from Sigma-Aldrich (Bornem, Belgium) and Milli-Q water was used (Millipore Systems, Guyancourt, Molsheim, France).

\subsection{Accessible free thiol content assay}

Free thiol contents of protein isolates were measured using Ellman's reagent, 5,5-dithiobis-2-nitrobenzoic (DNTB) (Ellman, 1959). Sodium phosphate buffer (0.1M, pH 8) containing 1mM EDTA was degassed under vacuum before use. Protein concentrates were dispersed with a solid:liquid ratio of 2.5 in sodium phosphate buffer containing DNTB $\left(0.3 \mathrm{~g}^{-L^{-1}}\right)$. Tube headspaces were filled in with argon or nitrogen and the tubes were incubated on a rotary shaker at $8^{\circ} \mathrm{C}$ for $15 \mathrm{~min}$ in the dark. The tubes were then centrifuged $(12000 \mathrm{xg}, 20 \mathrm{~min})$ and supernatant absorbance was measured at $412 \mathrm{~nm}$. The absorbance of the buffer and of the proteins in a non-reactive buffer (free of DNTB) was subtracted from the absorbance of the samples. The concentration of the released thionitrobenzoate ion (TNB ${ }^{2-}$ ) was calculated using a molar absorption coefficient of $13600 \mathrm{M}^{-1} \mathrm{~cm}^{-1}$. Results are expressed in micromoles of accessible free thiols per gram of protein.

\subsection{Sample preparation}

\subsubsection{Dough formulation}

Dough samples ( $3 \mathrm{~g}$ ) were prepared using wheat semolina, water and variable amounts of protein concentrates. A standard water content of $67 \%$ was used (dry mass basis) to obtain a homogeneous cohesive dough. Protein enrichments were carried out by replacing 0 to $10 \%$ of the semolina mass with a protein concentrate. Protein enrichment is hereafter expressed as the amount of added protein as a percentage of the total protein content of the protein-enriched dough. It ranged from $0 \%$ (control dough) to $33 \%$. When analysing protein interactions, the protein used for enrichment is called "extrinsic protein".

\subsubsection{Raw dough production}

Doughs were prepared using a "2-g Mixograph" (TMCO, Lincoln, NE, USA) equipped with a homemade aluminium double-walled jacket coupled with a water-regulated bath to control the temperature of the bowl. Wheat semolina and the protein concentrate were first mixed. The water was then added. The mixture was homogenised in the mixing bowl for six seconds at $54 \mathrm{rpm}$ at ambient temperature. The mixture was left to rest for $15 \mathrm{~min}$ at $40^{\circ} \mathrm{C}$ and cooled to $20^{\circ} \mathrm{C}$ over a period of $25 \mathrm{~min}$. The dough was then mixed at $54 \mathrm{rpm}$ for $220 \mathrm{~s}$. 
To study the effect of heat on protein polymerisation, a thermal treatment was applied to the mixed doughs. A hermetically sealed aluminium container (internal dimensions: $9 \mathrm{~mm}$ radius, $3 \mathrm{~mm}$ height) was made to contain $1.2 \mathrm{~g}$ of dough. Directly after mixing, the device was filled with $1.2 \mathrm{~g}$ of dough and immersed in a water bath at $80^{\circ} \mathrm{C}$ for three minutes. It was then cooled down on ice and the dough sample was removed and immersed in liquid nitrogen before freeze drying.

\subsection{Dough mechanical properties}

The mechanical properties of the raw doughs were analysed immediately after mixing. Dynamic mechanical thermal analysis (DMTA) with oscillatory measurements were performed as described in (Shehzad, Chiron, Valle, Lamrini, \& Lourdin, 2012). A controlled strain dynamic mechanical analyser (DMTA MK 4, Rheometric Scientific, USA) was used in compression mode at a frequency of $1 \mathrm{~Hz}$ with a $17 \mathrm{~mm}$ diameter plate-plate geometry. A sinusoidal strain was applied with strain amplitude of $0.10 \%$. The behaviour of wheat dough in dynamic measurements at this strain amplitude can be considered as linear (Lefebvre, 2006). A piece of dough weighing $0.90 \mathrm{~g}( \pm 0.02 \mathrm{~g})$ was placed between the two plates and the gap was set to $3.7 \mathrm{~mm}$ before the experiment. The dough faces in contact with the air were covered with grease to prevent water loss during measurement. Stress was recorded during a temperature ramp of $3^{\circ} \mathrm{C} / \mathrm{min}$ from ambient temperature to $140^{\circ} \mathrm{C}$.

To relate the oven temperature to the internal temperature of the dough, the temperature of two samples was measured using a thermocouple placed in the core of the dough. Using a polynomial model, an equation was determined to obtain the dough temperature from the oven temperature for all samples. The dynamic storage modulus, or elastic modulus ( $\left.E^{\prime}\right)$, was calculated using RSI Orchestrator software (Rheometric Scientific, USA).

\subsection{Analysis of protein polymerisation and protein/protein interactions}

\subsubsection{Extraction of the gluten-like fraction after dough mixing}

Samples of control and protein-enriched doughs were washed by hand under deionized water for 15 min to remove most of the starch and soluble material. The rubbery mass that remains is called the gluten-like fraction (GLF) because it is probably composed of other proteins than gluten ones when extracted from protein-enriched doughs. The GLF was then recovered on a $200 \mu \mathrm{m}$ sieve, immersed in liquid nitrogen and freeze-dried.

\subsubsection{Protein analysis in denaturing conditions}

SE-HPLC analysis of proteins was performed on protein concentrates, ground freeze-dried doughs and ground freeze-dried GLF. Protein was extracted as described in Morel, Dehlon, Autran, Leygue, \& Bar-L'Helgouac'H (2000) with some modifications. Proteins were first extracted in $0.1 \mathrm{M}$ sodium phosphate buffer $\mathrm{pH} 6.8$ with $1 \%$ SDS. Solid to liquid ratios of $8,0.8$ and 1.5 were used for the freeze-dried dough, protein concentrates and extracted gluten, respectively. Extraction was performed on a rotary shaker set at $60 \mathrm{rpm}$ at $60^{\circ} \mathrm{C}$ for $80 \mathrm{~min}$. SDS-soluble proteins were recovered in the supernatant after centrifugation ( $39191 \mathrm{x} \mathrm{g}, 30 \mathrm{~min}, 20^{\circ} \mathrm{C}$ ). SDS disrupts non-covalent bonds and allows small aggregates to dissolve (Khan, Huckle, \& Freeman, 1994). A second extraction was performed on pellets at $60^{\circ} \mathrm{C}$ for $60 \mathrm{~min}$, in the same buffer including $20 \mathrm{mM}$ dithioerythritol (DTE), to break the disulphide bonds. The pellets were then sonicated (Vibracell 72434, Bioblock Scientific, Illkirch, France) for three minutes at $50 \%$ power setting $20 \mathrm{kHz}$. Supernatants were recovered after centrifugation as described previously and diluted twice with $0.1 \mathrm{M}$ phosphate, 1\% SDS buffer including $40 \mathrm{mM}$ of iodoacetamide (IAM), to prevent reformation of the disulphide bonds. For readability, proteins insoluble in SDS but soluble in SDS and DTE are hereafter called "SDS+DTE soluble proteins".

The SE-HPLC apparatus (Waters model LC Module1 plus) was equipped with an analytical column, TSK G4000-SW $(7.5 \times 300 \mathrm{~mm})$ and a guard column, TSK G3000-SW (7.5 x $75 \mathrm{~mm})$ (both from Merck, Darmstadt, Germany). Apparent molecular weights were assessed with column calibration as described in Redl, Morel, Bonicel, Vergnes, \& Guilbert (1999). For the analysis, six peaks were defined on chromatograms of SDS soluble proteins: peak P1 corresponds to proteins eluted in the void volume, peak P2 corresponds to proteins whose molecular weight ranged from $157 \mathrm{kDa}$ to $763 \mathrm{kDa}$, peak P3 from 82 to $157 \mathrm{kDa}$, peak P4 from 50 to $82 \mathrm{kDa}$, peak P5 from 20 to 50 $\mathrm{kDa}$ and peak P6 from 6 to $20 \mathrm{kDa}$. The signal recorded after P6 does not correspond to proteins. The sum of the areas of the elution profiles of SDS-soluble and SDS+DTE soluble proteins, from peak P1 to peak P6, corresponds 
to the amount of total extractable proteins. The peak boundaries were defined according to the position of the peaks in the rubisco-enriched wheat dough, so they may not exactly correspond to the peaks of the other samples such as protein concentrates or control dough. The repeatability of dough production and protein extraction was assessed in triplicate on several samples (Supplementary fig. 1). Dough fabrication and protein extraction were then performed only once on each sample.

\subsubsection{Elution profile analysis}

Elution profiles were normalised on the basis of their total protein content before any calculation. To evaluate if protein enrichment altered protein polymerisation in wheat dough, a differential SE-HPLC profile was calculated. First, theoretical elution profiles of wheat proteins and extrinsic proteins of enriched dough were built. They correspond to the elution profile of the $100 \%$ wheat control dough and to the elution profile of the extrinsic protein concentrate, both normalised based on their respective proportion in the enriched dough studied. This is illustrated in Diagram 1 for wheat dough enriched at 20\% rubisco. If the protein enrichment of the wheat dough does not alter the polymerization of the proteins, then its elution profile corresponds to the sum of these two theoretical profiles.

Second, we subtracted the theoretical elution profile of wheat proteins from the experimental elution profile of protein-enriched dough. The resulting profile, called the differential profile, was compared to the elution profile of the extrinsic protein concentrate used for the enrichment. Any difference between the two latter profiles identifies changes in protein polymerisation induced by protein enrichment of the dough.

A similar approach was used to analyse the gluten-like fraction extracted from rubisco-enriched dough. As it cannot be excluded that some proteins were lixiviated during dough washing, the final proportion of rubisco and wheat proteins in the GLF is unknown. To calculate differential profiles, we considered that the extraction yield of wheat proteins in rubisco-enriched GLF was similar to that in the control wheat GLF. The resulting differential profile was compared to the elution profile of the rubisco concentrate. Considering the approximation used for the calculation, care must be taken in the interpretation of such differential profiles.
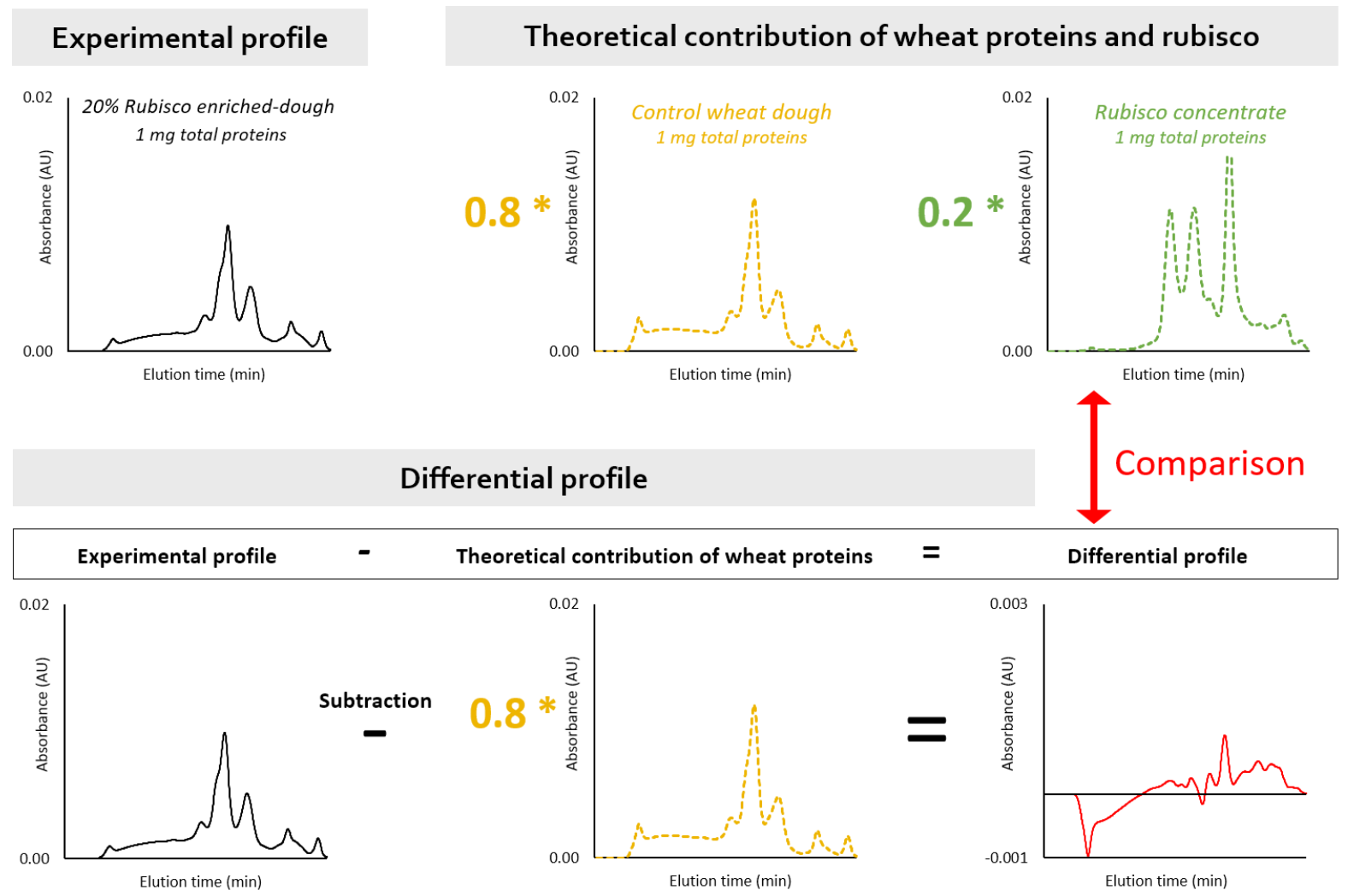

Diagram 1 Method for the analysis of elution profiles of protein-enriched samples: Example for a wheat dough 

CLSM was performed on control, $29.6 \%$ gluten-enriched dough, 33\% pea protein-enriched doughs and $31.9 \%$ rubisco-enriched doughs.

Frozen doughs were used for non-specific labelling of proteins. Samples were cut into $80 \mu \mathrm{m}$ thick slices at $-20^{\circ} \mathrm{C}$ using a cryotome (Microm HM $500 \mathrm{OM}$, Microm International GmbH, Germany). They were then placed on a cold glass coverslip and proteins were stained with $0.2 \mu \mathrm{L}$ of Alexa FluorTM 546 NHS Ester (Thermo Fisher Scientific, USA). The slices were then mounted on microscope slides.

Rubisco was specifically labelled to visualise its location compared to wheat proteins. Rubisco concentrate was first dispersed at $25 \mathrm{~g} . \mathrm{L}^{-1}$ in $0.1 \mathrm{M}$ sodium carbonate buffer at $\mathrm{pH} 9$ for five hours at ambient temperature. The dispersion was then centrifuged $(12000 \times \mathrm{g}, 20 \mathrm{~min})$. The supernatant was mixed with a $1 \%$ Fluorescein isothiocyanate (FITC) solution in dimethyl sulfoxide (DMSO) at a ratio of $0.015: 1$. After one hour of incubation, the sample was dialysed using a 6-8 kDa molecular weight cut off tubing (Spectra/Por ${ }^{\circledR}$, VWR, Leuven, Belgium) against water to remove free dyes for 26 hours with several changes of bath water. Specifically labelled rubisco was concentrated by osmotic compression against a $10 \%$ (wt/v) polyethylene glycol 20000 solution, until a protein concentration of $135 \mathrm{mg} \cdot \mathrm{mL}^{-1}$ was obtained. The protein concentration was estimated from the dry mass recovered after drying at $105^{\circ} \mathrm{C}$ for five hours. Doughs were prepared as described in 2.3.2, using a mix of unlabelled rubisco and fluorescein isothiocyanate (FITC) specifically labelled rubisco. AR software (Nikon, Germany). Samples were observed in confocal mode with a $561 \mathrm{~nm}$ and a 488 laser for Alexa FluorTM 546 NHS Ester and FITC label respectively. Emitted light was recovered with a filter at 515/30 and 595/50 $\mathrm{nm}$, respectively. Images (2048 pixels) were taken at a magnification of 40 and resolution of $0.16 \mu \mathrm{m} / \mathrm{px}$ in duplicate. 


\section{Results}

\subsection{Characterisation of protein concentrate}

Protein concentrates acquired from commercial or laboratory sources can vary considerably. Their protein content, the amount of accessible free thiols or their state of aggregation affects their functionality. For this reason, the concentrates used in this study were first characterised. Gluten, pea protein and rubisco concentrates contained respectively $67.2,77.5$ and $74.1 \%$ of protein (dry basis) as reported in Table 1.

Gluten proteins do not contain free thiols, or an amount below the limit of detection. When propan-2-ol was used as a solvent, a low free thiol content of $0.94 \pm 0.1 \mu \mathrm{mol} . \mathrm{g}^{-1}$ of vital gluten was reported (Morel, Bonicel, Micard, \& Guilbert, 2000). Pea proteins contain an average of $11.2 \mu \mathrm{mol}$ of free thiols per gram of protein as reported previously (O'Kane, Vereijken, Gruppen, \& van Boekel, 2005). Rubisco has a remarkably high free thiol content of $67.2 \pm 0.9 \mu \mathrm{mol} . \mathrm{g}^{-1}$. Lower free thiol contents $\left(13.66 \mu \mathrm{mol} . \mathrm{g}^{-1}\right)$ have been reported in the literature for rubisco from alfalfa (Hood, Cheng, Koch, \& Brunner, 1981). Gluten protein concentrate contains $88.9 \pm 0.7 \%$ of SDS soluble proteins as a function of total extractable proteins. In this study, pea protein concentrate contains $76.6 \pm 0.7 \%$ of SDS soluble proteins, whereas higher SDS solubility values (91.9\%) have been reported for protein from pea flour (Kristiawan et al., 2018). This suggests that industrial pea protein extraction causes higher aggregation of proteins. Rubisco has the highest solubility in SDS with $96.4 \pm 0.7 \%$ of extractable proteins.

SE-HPLC profiles of SDS soluble and SDS+DTE soluble proteins of the three protein concentrates are shown in Figure 1. SE-HPLC profile of wheat proteins is characterised by a large polydispersity comprising proteins from six to more than $1000 \mathrm{~kg} \mathrm{~mol}^{-1}$. This is related to the intrinsic diversity of wheat proteins, in particular of wheat prolamins. Peaks P1, P2 and P3 of SDS soluble proteins include proteins with molecular weights higher than $80 \mathrm{~kg}^{-\mathrm{mol}^{-1}}$ (Figure 1A). These peaks were attributed to glutenin polymers (Morel, Dehlon, et al., 2000). Peaks P4 and P5 correspond to proteins with molecular weights ranging from 20 to $80 \mathrm{~kg} \cdot \mathrm{mol}^{-1}$ and were attributed to gliadins. Peak P6, including proteins from six to $20 \mathrm{~kg} . \mathrm{mol}-1$, was attributed to wheat albumins and globulins. Three major peaks can be seen in the SDS+DTE soluble protein elution profile. The first eluting material extends from the upper column molecular exclusion size (about 2,000 kg. mol ${ }^{-1}$ ) to a peak centred at about $86 \mathrm{~kg} \cdot \mathrm{mol}^{-1}$. This peak is hypothesised to correspond to the high molecular weight (HMW) glutenin subunits released from glutenin polymers after disulphide bond reduction. The main following peak could correspond to low molecular weight (LMW) glutenin subunits of about 45 kg.mol ${ }^{-1}$. Finally, albumin and globulin that were initially disulphide-bonded to glutenin polymers were possibly eluted at about $15 \mathrm{~kg} \cdot \mathrm{mol}^{-1}$ (Veraverbeke \& Delcour, 2002). The elution profiles of pea proteins are presented in Figure 1B. The SDS soluble fraction includes two major peaks at 58-60 kg. mol ${ }^{-1}$ (P4) and 36-38 kg.mol-1 (P5) which may be attributed to alpha/beta dimers of legumin and to vicilin subunits, respectively (John A. Gatehouse, Croy, Morton, Tyler, \& Boulter, 1981). A shoulder is detected around $70-80 \mathrm{~kg} \mathrm{~mol}^{-1}$ which may be attributed to convicilin subunits (Croy, Gatehouse, Tyler, \& Boulter, 1980). Smaller polypeptides at 22, 17 and $14 \mathrm{~kg} \cdot \mathrm{mol}^{-1}$ are also visible. These polypeptides cannot be attributed firmly based on molecular weights as they could correspond to alpha, beta chains of legumins (Matta, Gatehouse, \& Boulter, 1981), to vicilin peptides (John A. Gatehouse et al., 1981) or pea albumins (Croy, Hoque, Gatehouse, \& Boulter, 1984; J. A. Gatehouse, Gilroy, Hoque, \& Croy, 1985). A fraction of proteins displayed a molecular weight higher than $100 \mathrm{~kg} \cdot \mathrm{mol}^{-1}$, probably corresponding to aggregated proteins. The fraction of SDS-insoluble pea protein released after reduction of DTE contains several peaks, the same peaks as those in the SDS soluble protein profile, along with large species $\left(>200 \mathrm{~kg} \cdot \mathrm{mol}^{-1}\right)$, suggesting that some of the SDS-insoluble aggregates are stabilised by, at least, disulphide bridges. Industrial pea proteins are complex mixtures of proteins. In reduced conditions, it is difficult to attribute the nature of polypeptides based on their molecular weight. Other technics based on immunospecificity would be required. The elution profile of rubisco SDS-soluble protein fraction includes three well defined peaks (Figure 1C1). The main fraction was eluted in P6 (16.4 min) and was attributed to the small chain of rubisco (SC), with a molecular weight of about $15 \mathrm{~kg} \cdot \mathrm{mol}^{-1}$. The peak eluted between P4 and P5

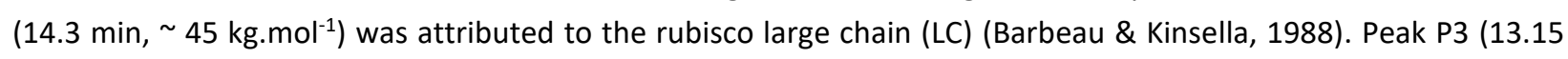
$\mathrm{min}, \sim 100 \mathrm{~kg}^{\mathrm{mol}}{ }^{-1}$ ) could corresponds to large-chain dimers that may be formed during the extraction process (Rintamaki, 1989). This dimer was not detected when proteins were directly extracted in the presence of SDS and DTE (data not shown). Moreover, only two peaks attributed to the small and large subunits are present in SDS+DTE soluble fraction (Figure 1C2, inset), suggesting that interchain disulphide bonds would stabilise LC dimer. A shoulder 
272 visible between P5 and P6 in the SDS soluble protein profile corresponds to a molecule of about $28 \mathrm{~kg}^{\mathrm{mol}} \mathrm{m}^{-1}$ of 273 unknown origin. At the elution time of this peak, the ratio of intensity at $260 \mathrm{~nm}$ with $214 \mathrm{~nm}$ is much higher than 274 for the other peaks (data not shown). This suggests that this molecule is richer in groups that absorb at 260 than

275 other proteins of the extract. The molecular weight is too high to correspond to phenolic compound but this 276 molecule could be a protein linked with phenolic compounds. 
Table 1 Characterisation of protein concentrates: protein content, accessible free thiol content and protein sequential solubility in denaturing buffer (SDS) and reducing buffer (SDS+DTE). "N.d" stands for "not determined". Standard deviations are expected to be similar to the standard deviations obtained on rubisco concentrate.

\begin{tabular}{|c|c|c|c|c|c|c|c|c|c|c|}
\hline \multirow[b]{2}{*}{ Gluten } & $\begin{array}{c}\text { Protein content } \\
\text { mg/100 g of } \\
\text { concentrate, dry } \\
\text { basis } \\
\end{array}$ & \multicolumn{3}{|c|}{$\begin{array}{l}\text { Free thiol content } \\
\mu \mathrm{mol} / \mathrm{g} \text { of protein }\end{array}$} & SDS so & ubl & rotein & \multicolumn{3}{|c|}{$\begin{array}{l}\text { SDS+DTE soluble } \\
\text { proteins }\end{array}$} \\
\hline & $67.2 \pm$ & 0 & \pm & 0.1 & 88.9 & \pm & n.d & 11.1 & \pm & n.d \\
\hline Pea protein & 77.5 & 11.2 & \pm & 0.1 & 76.6 & \pm & n.d & 23.4 & \pm & n.d \\
\hline Rubisco protein & 74.1 & 67.2 & \pm & 0.9 & 96.4 & \pm & 0.7 & 3.6 & \pm & 0.7 \\
\hline
\end{tabular}
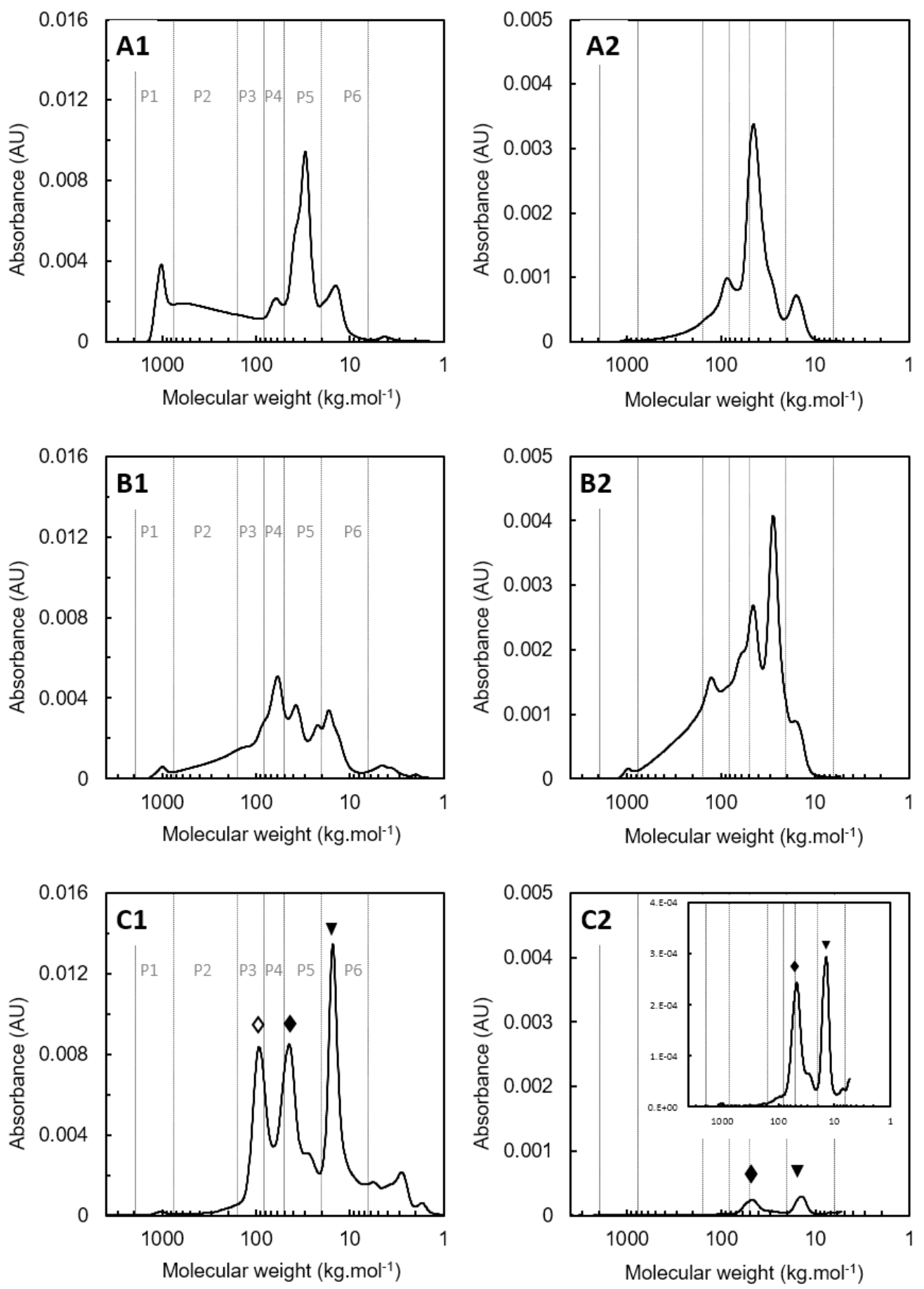
Figure 1 Elution profiles of SDS soluble protein fractions (1; left) and SDS+DTE soluble protein fractions (2; right) extracted from gluten (A), pea protein (B) and rubisco $(C)$ concentrates. The inset in $C 2$ is a close-up of the elution profile. The symbols in figure $\mathrm{C} 1$ and $\mathrm{C} 2$ represent rubisco subunits: small chain (SC: $\boldsymbol{\nabla}$ ), large chain (LC: $\downarrow)$ and large chain dimer (LC dimer: $\diamond)$. For the sake of readability, the two types of elution profiles are not represented at the same scale and the elution profile of SDS+DTE soluble proteins is represented only from $6 \mathrm{~kg}$. mol-1. Every experimental elution profile is represented after normalisation based on $1 \mathrm{mg}$ of total protein in the sample.

\subsection{Influence of protein enrichment on dough stiffening during heating}

288

Temperatures above $50^{\circ} \mathrm{C}$ are known to trigger protein polymerisation and starch gelatinisation, and thus to affect wheat dough mechanical properties (Bloksma, 1972). Therefore, to understand the effect of protein enrichment on the structuring of dough during thermal treatment, changes in mechanical properties of doughs prepared at several enrichment rates were assessed during a temperature ramp. Representative curves of elastic modulus $\left(E^{\prime}\right)$ as a function of the core sample temperature for control and $\sim 32 \%$ extrinsic protein-enriched doughs are shown in Figure 2A. All samples exhibited the same trend. When the temperature was increased up to $50^{\circ} \mathrm{C}, \mathrm{E}^{\prime}$ decreased (Zone I) due to an increase in water and polymer chain mobility (Bloksma, 1990), followed by a marked increase in $E^{\prime}$ between $50^{\circ} \mathrm{C}$ and $75^{\circ} \mathrm{C}$ reflecting dough stiffening (Zone II). This increase corresponds to the cumulative effect of starch gelatinisation and protein aggregation. However, there is no clear scientific consensus on which of the two phenomena dominates the elastic modulus response in these temperature ranges. The maximum value of the elastic modulus has been shown to be positively correlated with the starch content in starch-gluten blends while gluten is assumed to have little influence on E' values (Dreese, Faubion, \& Hoseney, 1988; Mario Jekle, Mühlberger, \& Becker, 2016a; Zanoletti et al., 2017). Conversely, some studies on wheat doughs reported that changes in $E^{\prime}$ with temperature are mainly due to the polymerisation of gluten proteins (Rouillé, Chiron, Colonna, Della Valle, \& Lourdin, 2010). Beyond $75^{\circ} \mathrm{C}$, the elastic modulus decreased almost linearly (zone III). The mechanism related to this change is not well established in the literature as reviewed in Vanin, Michon, \& Lucas, (2013). Several studies on gluten, pea or rubisco proteins system report an increase or a stabilisation of $E^{\prime}$ values at these temperatures (Felix, Perez-Puyana, Romero, \& Guerrero, 2017; Martin et al., 2014; Wang et al., 2017). Therefore, elasticity drop above $75^{\circ} \mathrm{C}$ may be associated with the softening of swollen starch granules. The peak of elastic modulus is representative of the maximal structural hardening of the dough. The change in maximum value of $E^{\prime}\left(E^{\prime}\right.$ max), is shown on Figure 2B as a function of the protein enrichment and total protein contents for the three proteins studied. $E_{\text {max }}$ values of doughs enriched at $8 \%$ were lower than the control dough regardless of the type of protein used. Gluten, pea proteins and rubisco alter dough thermal structuring similarly at $8 \%$ of protein enrichment. Beyond $8 \%$, two types of behaviour were observed depending on the protein used for enrichment. Enrichment in gluten and pea proteins caused a further decrease in $\mathrm{E}_{\text {max }}^{\prime}$ of about $36 \%$ compared to the control dough, suggesting that either starch gelatinisation or gluten polymerisation rates decrease with the incorporation of more pea and gluten proteins. In contrast, enrichment with rubisco beyond $8 \%$ resulted in $E^{\prime}{ }_{\max }$ values similar to those of the control dough, demonstrating its capacity to preserve the elastic behaviour of dough.

The loss factor, $\tan (\delta)$, represents the viscous to elastic ratio of dough and thus gives an estimate of the extent of dough structuring (M. Jekle \& Becker, 2011). Figure 3 shows how it changed with temperature in control dough, $29.6 \%$ gluten-enriched dough, $33.0 \%$ pea protein-enriched dough and $31.9 \%$ rubisco-enriched dough. Its value was less than 1 and continuously decreased from 25 to $95^{\circ} \mathrm{C}$ in all samples. $A \tan (\delta)$ value below 1 is typical of elastic material and a decrease indicates a gain in dough stiffness. The gluten-enriched dough displayed the same changes in $\tan (\delta)$ as the control dough with slightly higher values, meaning that an increase in gluten content increases the liquid-like behaviour of dough. The $\tan (\delta)$ of pea protein-enriched dough was close to that of the control dough below $47^{\circ} \mathrm{C}$. It then decreased but less markedly than in the control dough, ultimately leading to a substantially higher value of $\tan (\delta)$. Pea proteins reduce the gain in elasticity of the semolina dough during heating. The loss factor of rubisco-enriched doughs was significantly higher than that of the control dough and remained stable from 25 to $40^{\circ} \mathrm{C}$. It then dropped abruptly to reach a value similar to that of the gluten-enriched dough at $65^{\circ} \mathrm{C}$. This suggests that, between 40 and $65^{\circ} \mathrm{C}$, rubisco contributes to dough elasticity while below $40^{\circ} \mathrm{C}$, it acts as a diluent increasing the liquid behaviour of the sample. It should be noted that beyond $70^{\circ} \mathrm{C}, \tan (\delta)$ values of doughs enriched in either 

dough structure.

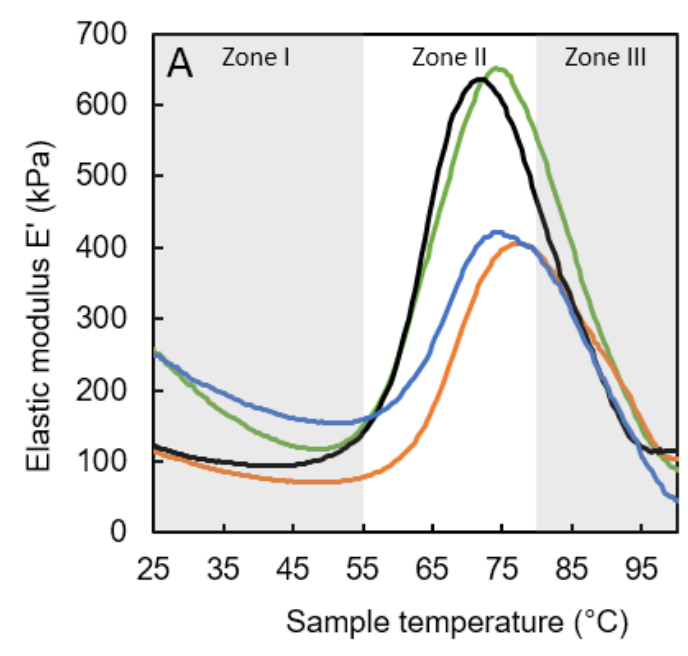

331

Figure 2 A Thermal variation of elastic modulus determined by DMTA in control (black) sample and $29.6 \%$ gluten (orange line), 33.0\% pea protein (blue line) and 31.9\% rubisco (green line) enriched doughs. The curves are representative of triplicate observations. B: Comparison of E' max values measured by DMTA on gluten-enriched doughs (o), pea protein-enriched doughs $(\Delta)$ and rubisco-enriched doughs $(\diamond)$ at several enrichment rates.

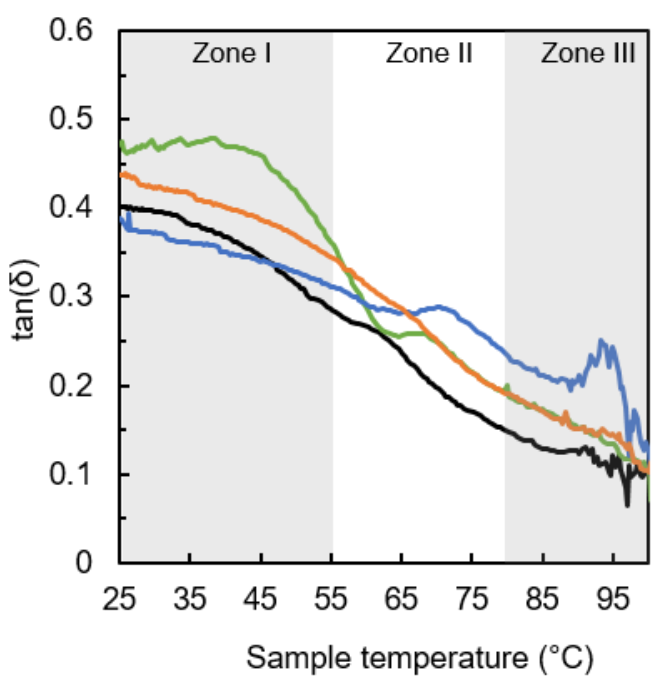

Figure 3 Thermal variation of loss factor $\tan (\delta)$ determined by DMTA in control (black) sample and 29.6\% gluten (orange line), 33.0\% pea protein (blue line) and 31.9\% rubisco (green line) enriched doughs. The curves are averages of triplicate observations.

\subsection{Protein polymerisation in thermally treated doughs}

To identify heat-induced changes in protein interactions, proteins from dough samples treated at $80^{\circ} \mathrm{C}$ for three minutes were successively extracted in SDS and then in SDS+DTE buffers and analysed by size-exclusion chromatography. Experiments were performed on control and $14.9 \%$ gluten, $17.1 \%$ pea protein and $16.3 \%$ rubiscoenriched doughs.

The differential SE-HPLC profiles of each protein-enriched dough were calculated and compared to the SE-HPLC experimental profile of the extrinsic protein concentrate (as described in 2.5.3). Results concerning the SDS-soluble protein fractions are shown in Figure 4A, B and C. Figure 4D shows the same kind of profiles for SDS+DTE soluble 
proteins in rubisco-enriched doughs. Differences between differential and protein concentrate profiles, when present, can be linked to a change in the size distribution of the extrinsic protein or to the effect of enrichment on the overall heat-induced protein polymerisation whatever the protein considered, either extrinsic or wheat protein. The impact of protein enrichment on protein polymerisation depends on the type of protein. The differential profile corresponding to gluten-enriched dough is below the gluten concentrate profile, especially at the location of glutenin polymers (Figure $4 \mathrm{~A}$ ). Hence, the areas of peaks P1 and P2 are respectively $46 \%$ and $24 \%$ lower than in the gluten concentrate profile. A decrease of the same magnitude was observed between raw control doughs and thermally treated control dough (data not shown). This suggests that the differences observed between the differential profile of gluten-enriched dough and the gluten concentrate profile could reflect the effect of heating on extrinsic glutenin polymers. The differential profile of pea protein-enriched dough does not differ much from the pea protein concentrate elution profile (Figure 4B). Peaks P4, P5 and P6 are only about $10 \%$ lower than those of the raw pea

359 concentrate profile

The differential profile of the SDS-soluble fraction obtained from the heated rubisco-enriched dough contrasted sharply with that of raw rubisco as shown in Figure 4C. The differential profile shows negative P1 and P2 peaks, corresponding, in the mirror image, to peaks of wheat glutenin polymers. In addition, the typical rubisco peaks, $\mathrm{P} 3$, P4 and P6, almost disappeared, implying that enrichment in rubisco makes these wheat and rubisco protein fractions insoluble in SDS. Moreover, the differential profile of SDS+DTE soluble proteins is well above that of the SDS+DTE soluble protein in the rubisco concentrate (Figure 4D). In Figure 4D, peak P3 may correspond to high-molecularweight glutenin subunits as described previously, while peak P5 and P6 may partly correspond to rubisco LC and rubisco SC. The fact that addition of DTE allowed the release of these subunits from the SDS-insoluble protein pellet indicates that protein insolubility was driven by disulphide crosslinking. The same analyses performed with increasing levels of rubisco enrichment showed that the concentration of rubisco affected the formation of disulphide-linked SDS-insoluble aggregates (not shown). Whether rubisco and wheat protein interact to form mixed aggregates was not established with the present analysis. However, it is likely that rubisco increases the heatinduced aggregation of wheat glutenin polymers. 

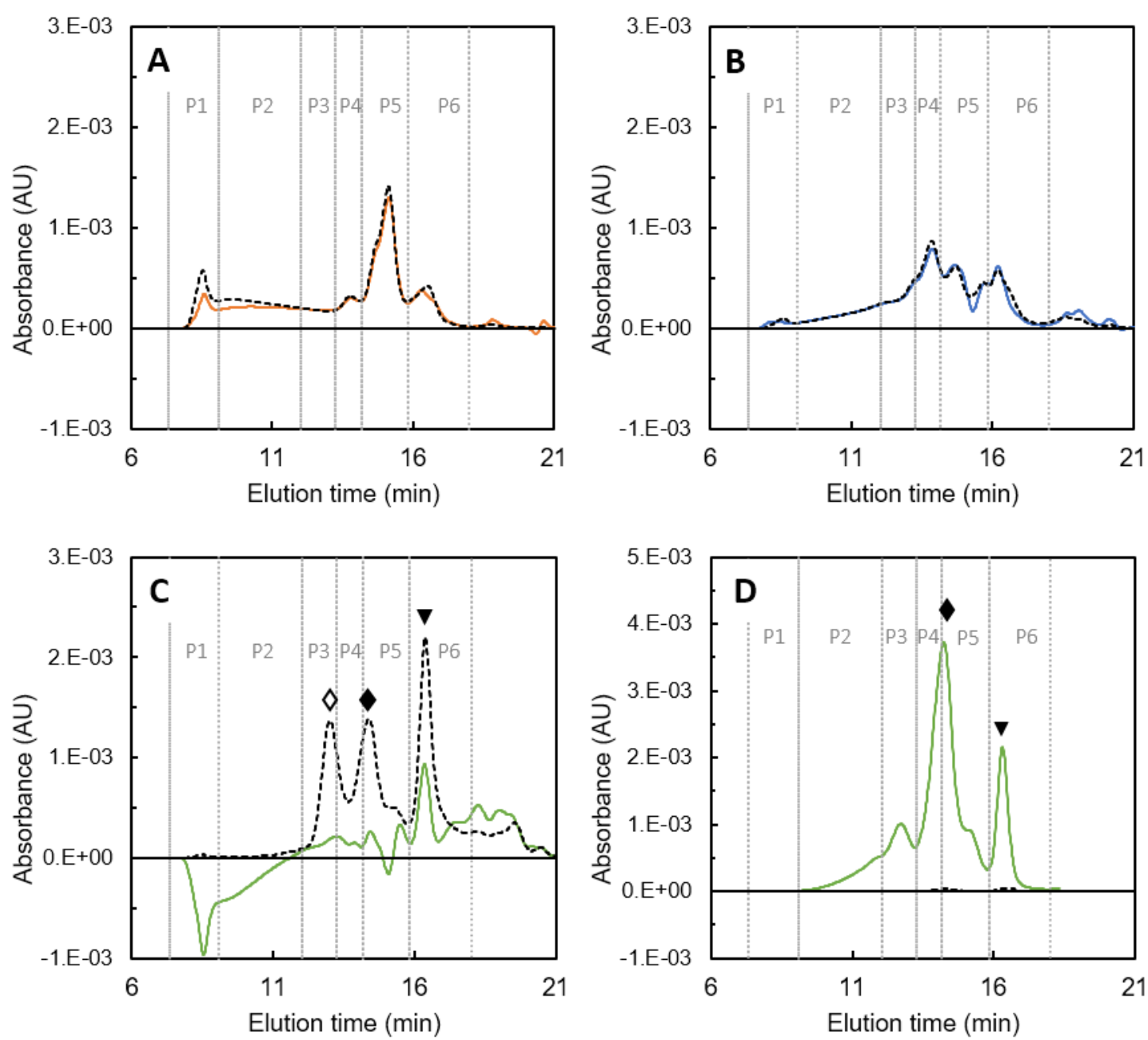

373

Figure 4: SDS soluble (A, B, C) and SDS+DTE soluble (D) differential profiles (solid lines) obtained from heat-treated doughs enriched with gluten $(A)$, pea proteins $(B)$ and rubisco $(C, D)$ compared with elution profile of extrinsic protein extracts (dashed line) adjusted to the same extrinsic protein weight. Differential profiles were obtained by subtracting the SE-HPLC elution profile of heat-treated wheat control dough from the elution profile of the heattreated enriched doughs (both adjusted to the same semolina weight). Doughs enrichment were $14.9 \%$ gluten ( $A$ ), $17.1 \%$ pea protein $(B)$ and $16.3 \%$ rubisco (C and D). Symbols represent rubisco subunits: small chain (SC: $\nabla)$, large chain (LC: $\diamond$ ) and large chain dimer (LC dimer: $\diamond)$. For the sake of readability, the elution profile of figure D is represented only up to $18 \mathrm{~min}$.

\subsection{Effect of incorporating rubisco on protein interaction during hydration and dough mixing}

Incorporating rubisco enhanced wheat protein polymerisation in thermally treated doughs. Experiments were conducted to check whether the modifications are related to heat treatment or take place during the hydration and dough mixing steps. To this end, the differential SE-HPLC profile of SDS soluble proteins from $37.4 \%$ rubisco-enriched raw dough was compared to the SE-HPLC profile of the rubisco concentrate (as described in 2.5.3). Noteworthy differences were observed between the differential profile and the elution profile of the concentrate, as shown in Figure 5. Like in thermally treated dough, peak P1 is negative on the differential profile, suggesting that the presence of rubisco may have reduced wheat glutenin polymer solubility in SDS. However, part of peak P2 is positive. Taken together, these features show that the addition of rubisco shifted the size distribution of wheat glutenin polymers towards smaller polymers. Peak P3, corresponding to rubisco LC dimer, is slightly shifted on the left in the early elution stage, which could be due to incorrect separation between it and peak P2. Peaks P5 and P6, corresponding to rubisco LC and SC, respectively, are lower than in the rubisco concentrate profile. This suggests that rubisco LC and SC aggregate during mixing. These peaks are higher than in theory in SDS+DTE soluble protein elution profile 
(Supplementary fig. 2). Rubisco LC and SC may therefore form SDS-insoluble disulphide-linked complexes, between each other or with wheat proteins, during hydration and mixing. Moreover, a negative peak can be seen after the rubisco LC peak (P5). It means that rubisco enrichment affected the molecular weight of proteins that are supposed to be eluted in this zone. It may correspond to a deficit in wheat gliadins and may also be due to the disappearance of rubisco $L C$.

In contrast to thermally treated doughs, the content of SDS-insoluble polymers did not increase with increasing doses of rubisco. However, a dose effect was observed for specific peaks (Figure 6). P2 and P3 areas are higher on the differential profiles than on the rubisco concentrate profile and the difference between the two profiles increased with increasing rubisco enrichment of the dough. The opposite was observed for P4 and P5 whose recovery decreased with increasing rubisco enrichment. With an increase in the rubisco/wheat protein ratio, the size of glutenin polymers decreased and the solubility of the LC and SC subunits in SDS decreased. Incorporating rubisco modified the molecular interactions during dough mixing with an effect of dose. The size of SDS soluble glutenin polymers decreased and rubisco LC and SC formed disulphide linked aggregates.

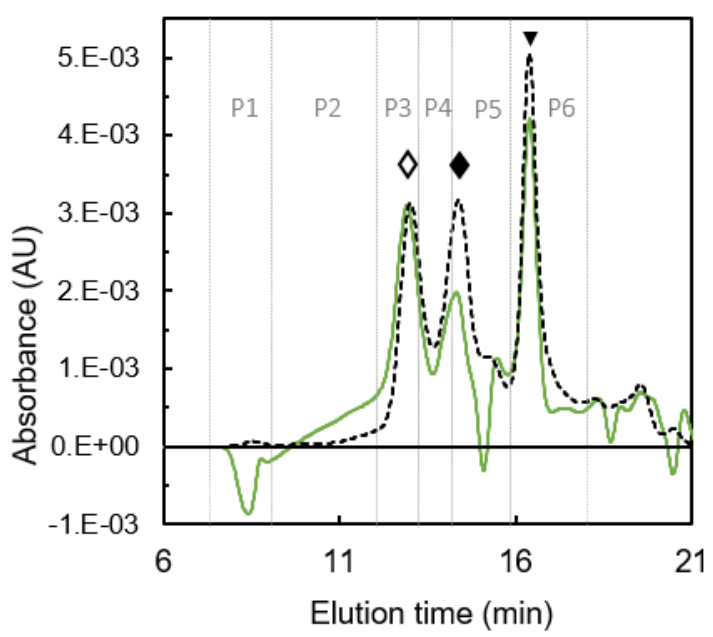

Figure 5 Differential SE-HPLC profile (green line) of raw dough enriched at $37.4 \%$ rubisco compared to SE-HPLC profile of rubisco protein concentrate (dashed black line) based on the same rubisco concentrate weight. The differential profile was obtained by subtracting the SE-HPLC profile of SDS-soluble proteins of wheat control raw dough from the profile of rubisco-enriched raw dough (both adjusted to same semolina weight). Symbols represent rubisco subunits: large chain dimer (LC dimer; $\diamond)$, large chain (LC; $\bullet$ ), small chain (SC; $\mathbf{\nabla})$.

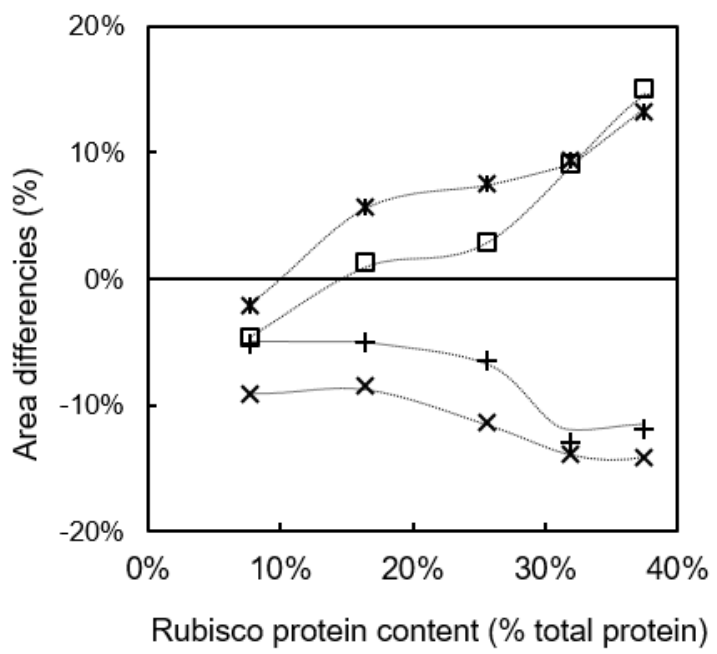

Figure 6 Differences of area under the curve for peaks P2 ( $\square$ ), P3 (*), P4 (+) and P5 (x) between experimental and theoretical elution profiles obtained for rubisco-enriched doughs at several rubisco enrichment rates. Theoretical 


\begin{tabular}{|c|c|c|c|c|c|c|c|c|c|}
\hline \multirow[b]{2}{*}{ Control wheat dough } & \multicolumn{3}{|c|}{$\begin{array}{l}\text { GLF weight } \\
g(d b)\end{array}$} & \multicolumn{3}{|c|}{$\begin{array}{l}\text { Protein content } \\
g / 100 g \text { of } G L F(d b)\end{array}$} & \multicolumn{3}{|c|}{$\begin{array}{l}\text { Protein extraction yield } \\
\% \text { of dough total proteins }\end{array}$} \\
\hline & 0.225 & \pm & 0.009 & 75.0 & \pm & 0.1 & 67.1 & \pm & 2.9 \\
\hline $\begin{array}{l}16.3 \% \text { rubisco-enriched } \\
\text { dough }\end{array}$ & 0.257 & \pm & 0.002 & 75.1 & \pm & 1.6 & 66.4 & \pm & 0.9 \\
\hline
\end{tabular}

To assess the presence of rubisco in the GLF of rubisco-enriched dough, proteins of GLF from control and enriched

profiles correspond to the sum of the elution profiles of the $100 \%$ wheat control dough and of the rubisco concentrate, both normalised based on their respective proportion in the enriched dough. Differences in peak area are expressed as a percentage of the theoretical profile. Dotted lines are included to guide the eye.

\subsection{Weak bond formation during hydration and mixing}

Previous results suggest that the introduction of rubisco affects molecular interactions in wheat dough. To highlight a possible effect of rubisco on gluten network specifically, gluten-like fraction (GLF) were recovered from control and rubisco-enriched raw doughs (16.3\%). Extraction yields in dry mass and protein content are listed in Table 2 . A higher amount of GLF was recovered from rubisco-enriched dough than from control dough. Given their similar protein content, it can be concluded that enriching the dough with rubisco increased the quantity of water-insoluble proteins. This could be related to an increased contribution of wheat proteins, and/or of rubisco in GLF.

Table 2 Extraction yield and protein content of gluten-like fractions extracted from control and rubisco-enriched doughs. dough were sequentially extracted in SDS and SDS+DTE and analysed by SE-HPLC. Raw elution profiles of GLF from control and rubisco-enriched doughs are given in supplementary data (Supplementary fig. 3). We hypothesised that the extraction yield of wheat proteins in rubisco-enriched GLF was similar to that in the control wheat GLF (detailed in part 2.5.3). This equates to estimating that $84.5 \%$ of the proteins of the rubisco-enriched GLF are wheat proteins and $15.5 \%$ are rubisco. The differential profile of rubisco-enriched GLF is compared to the elution profiles of rubisco concentrate in Figure 7. The SDS-soluble fraction of rubisco-enriched GLF shows a higher peak P2, meaning that rubisco increases the concentration of medium size glutenin polymers in the GLF.

The presence of peaks of the rubisco subunits (P3, P5 and P6) on the differential SE-HPLC profile means they are coextracted with wheat proteins during dough washing. The heights of peaks P3 and P6, corresponding to rubisco LC dimer and SC, are similar on the elution profiles of both differential and rubisco concentrate. Most LC dimers and SC are therefore water-insoluble but SDS-Soluble. This suggests that their water-insolubility is related to the establishment of weak interactions. In contrast, the height of the rubisco LC peak is lower on the differential profile than on the rubisco concentrate profile but higher on the SDS+DTE profile. This suggests that rubisco LC form waterinsoluble aggregates stabilised by disulphide bounds during mixing. 

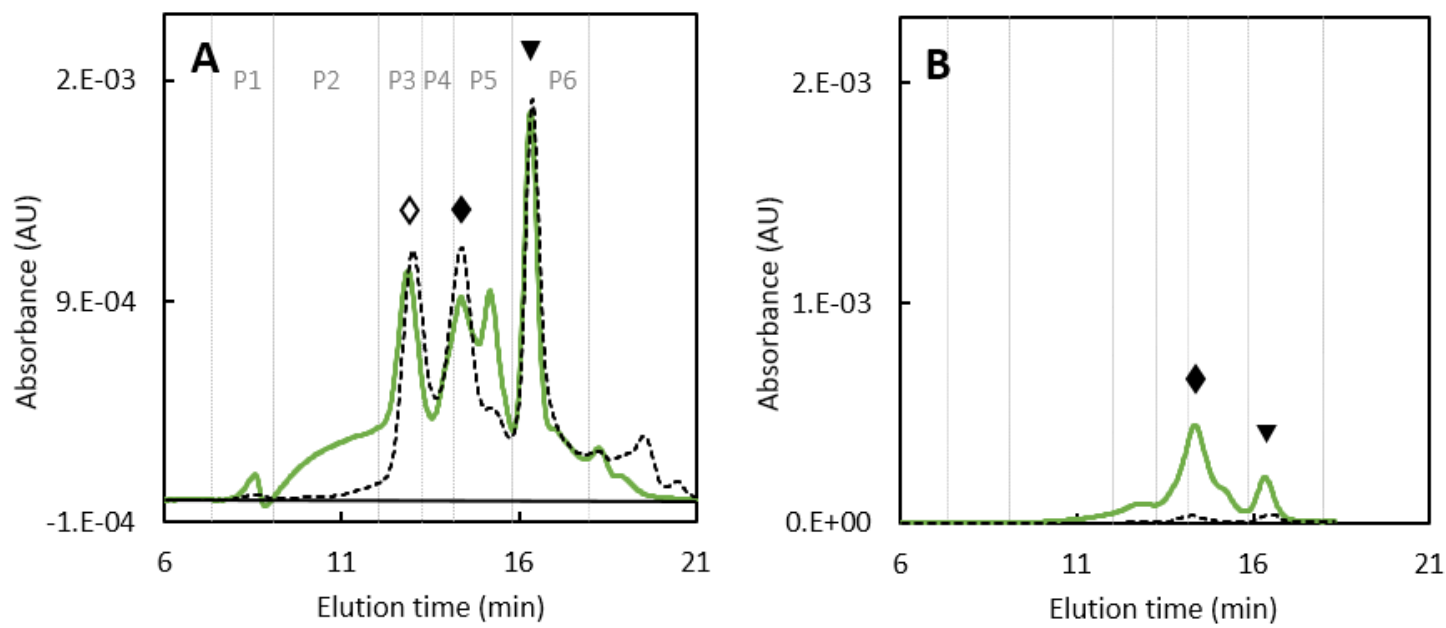

Figure 7: SDS soluble (A) and SDS+DTE soluble (B) differential profiles obtained for the gluten-like fraction (GLF) extracted from dough enriched with $16.3 \%$ rubisco (solid lines) compared with elution profile of rubisco concentrate (dashed lines) adjusted to the same rubisco weight. Differential profiles were obtained by subtracting the SE-HPLC elution profile of control GLF from the elution profile of the rubisco-enriched GLF. The calculation was made considering that the semolina protein extraction yields were the same for both gluten-like fractions. Symbols represent rubisco subunits: small chain (SC: $\nabla$ ), large chain (LC: $\diamond$ ) and large chain dimer (LC dimer: $\diamond)$.

\subsection{Microstructure of the dough protein network}

The microstructure of the protein network was visualized by confocal laser scanning microscopy (CLSM). The overall arrangement of the protein network was observed by non-specific covalent labelling of proteins from control dough, $29.6 \%$ gluten-enriched dough, 33\% pea protein-enriched dough and $31.9 \%$ rubisco-enriched dough. The resulting images are shown in Figure 8. The protein network of the control wheat dough (Figure 8a) has a typical honeycomb arrangement embedding starch granules (McCann \& Day, 2013). Gluten-enriched dough has a very similar structure (Figure 8b). Large protein particles are visible in the pea protein-enriched wheat dough micrograph (Figure 8c). Since the emission of these structures is intense, the gluten protein network must be examined at a lower intensity to avoid image saturation. Finally, the rubisco-enriched wheat dough has a slightly different protein network than the control wheat dough. Indeed, the extent of the protein network seems to be less uniform with higher lacunar zones. Further image analyses are needed to confirm this observation.

In order to reveal the segregation or co-location of rubisco and gluten, doughs were prepared using covalentlylabelled rubisco. CLSM images (Figure $\mathbf{8 d \mathbf { 1 }}$ and $\mathbf{d 2}$ ) show that rubisco does not form aggregated structures visible at the micro-scale in contrast with pea proteins. Instead, it is co-localized with the gluten protein network. 


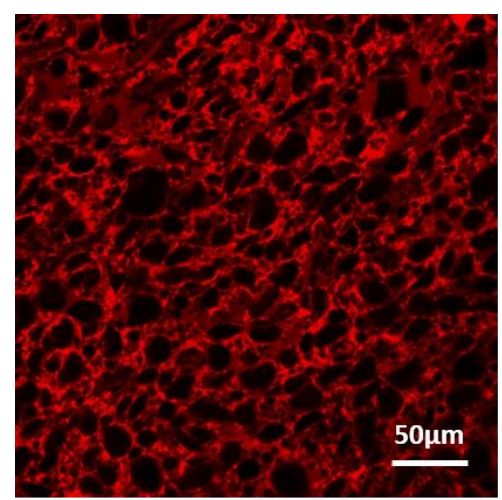

a: Control dough

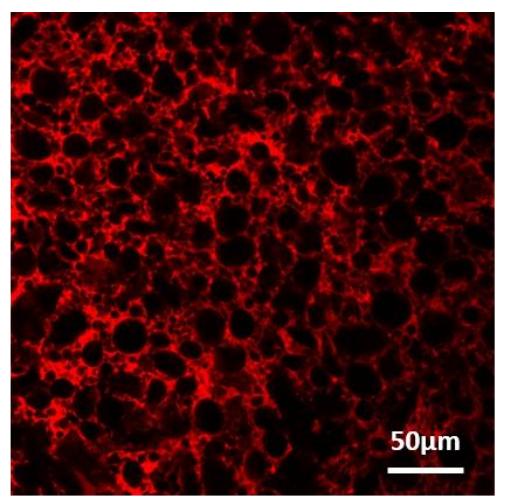

b: Gluten-enriched dough

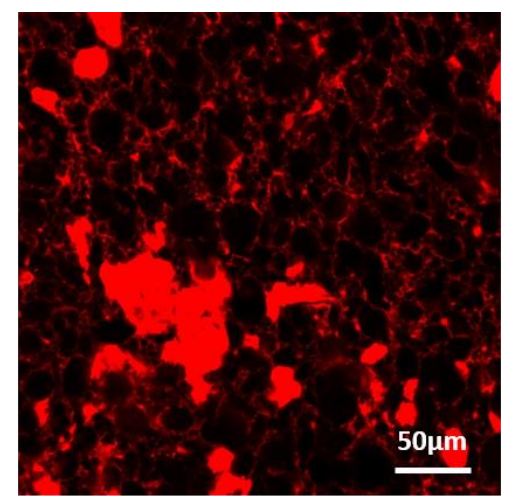

c: Pea protein-enriched dough

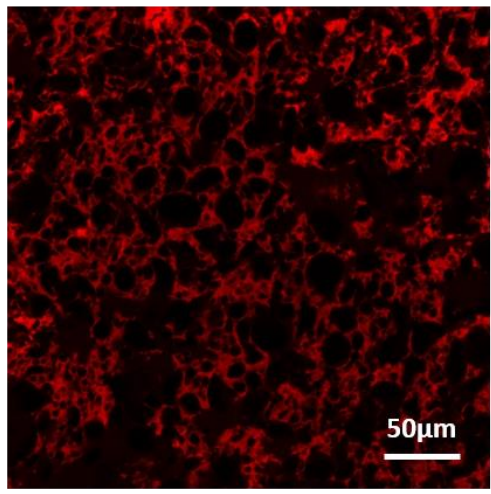

d1: Rubisco-enriched dough

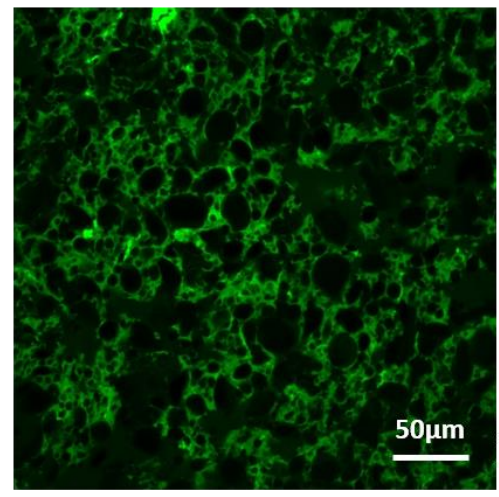

d2: Rubisco-enriched dough Specific labelling

Figure 8 CLSM images of control wheat dough (a), 29.6\% gluten-enriched dough (b), 33\% pea protein-enriched dough and 31.9\% rubisco-enriched dough (d1, d2). Proteins were stained using Alexa FluorTM 546 NHS Ester (in red in the images) in all samples. Only the rubisco-enriched dough has double labelling: rubisco was specifically labelled with FITC (in green in the images) before it was incorporated in the dough.

\section{Discussion}

Rubisco concentrate was used to improve the nutritional profile of wheat semolina dough. In comparison to gluten and pea proteins, rubisco exhibited specific behaviour. Indeed, adding rubisco preserved the elastic potential of wheat dough in contrast to adding gluten and pea protein. Rubisco sub-units formed both weak and covalent bonds, with a probable interaction with wheat proteins.

\section{Unlike pea proteins or gluten, adding rubisco enhanced wheat dough stiffening during a temperature ramp}

Dilution of wheat semolina with increasing concentrations of extrinsic gluten reduced the rise in elastic modulus between $55^{\circ}$ and $80^{\circ} \mathrm{C}$ and shifted $\tan (\delta)$ to higher values. However, the addition of gluten did not modify the drop of $\tan (\delta)$ during heating, which remained parallel to that of the standard wheat dough. Similar mechanical changes have already been reported in wheat doughs (N. M. Edwards, Dexter, Scanlon, \& Cenkowski, 1999) and in proteinstarch-water systems (Hibberd, 1970). Thus, a decrease in the starch-gluten ratio in wheat dough increases the liquid-like behaviour of dough (rise of $\tan (\delta)$ ) and limits the rise of the elastic modulus during heating. In addition, SE-HPLC analysis of SDS-soluble proteins from thermally treated gluten-enriched wheat dough demonstrated that adding gluten does not alter protein crosslinking during heating. Furthermore, extrinsic gluten and native semolina proteins were shown to behave similarly, forming SDS insoluble aggregates under thermal treatment. Thus, the decrease in $\mathrm{E}^{\prime}$ values in gluten-enriched wheat doughs is not related to a change in gluten protein polymerisation but rather to a change in starch gelatinisation. Several authors reported that adding gluten in starch-gluten blends can affect the starch gelatinisation rate and extent due to competitive hydration or by hindering water diffusion (Mario Jekle, Mühlberger, \& Becker, 2016b). Further analysis by differential scanning calorimetry (DSC) is now needed to determine if extrinsic gluten can act as a water trap. 
Similarly, the enrichment of wheat dough in pea proteins reduced $E^{\prime}$ max values with no major modification of wheat protein crosslinking upon heating. It can be concluded that like gluten, pea proteins compromise starch gelatinisation. Moreover, pea protein-enriched doughs presented the highest $\tan (\delta)$ values above a temperature of $65^{\circ} \mathrm{C}$, meaning that the relative viscous part of the dough increased as a result of the addition of pea protein. This could be related to the higher water-binding capacity of pea proteins compared to gluten proteins (Bravo-Núñez, Garzón, Rosell, \& Gómez, 2019; Peters, Vergeldt, Boom, \& van der Goot, 2017). In addition, CLSM images of enriched doughs revealed the presence of large protein particles, likely from pea proteins. They can affect the structure of the wheat gluten network due to steric hindrance. Several studies have shown that pea or faba bean enrichment reduces pasta quality by diluting the gluten network (Laleg et al., 2017; Petitot et al., 2010).

Finally, rubisco enrichment of less than $8 \%$ affected the mechanical properties of dough in the same way as gluten or pea proteins, suggesting that starch gelatinisation is similarly compromised. However, above $8 \%$, the addition of rubisco maintained a notable rise in $\mathrm{E}^{\prime}$ during heating in a similar way to control dough. Rubisco contributes to the elastic and viscous properties of the system. Rubisco may not act as a water trap like extrinsic gluten or pea protein and may allow starch gelatinisation proceed with no hindrance. In addition, rubisco enhances the formation of disulphide-linked protein aggregates upon dough heating that may strengthen dough mechanical properties. Incorporating rubisco in dough also increases the $\tan (\delta)$ values up to a temperature of $65^{\circ} \mathrm{C}$. This increase in the liquid-like behaviour of the dough may be related to the decrease in the concentration of $\mathrm{HMW}$ glutenin polymers. The further decrease in $\tan (\delta)$ values above $70^{\circ} \mathrm{C}$ may be related to the formation of large disulphide-linked polymers in thermally treated rubisco-enriched wheat doughs.

In this study, rubisco differed from pea proteins, which do not react with semolina protein. However, other legume proteins, such as soy proteins, are able to form disulphide-bonded polymers when incorporated in wheat dough (Ribotta, León, Pérez, \& Añón, 2005). But contrary to rubisco, this enrichment impairs the gluten network by reducing the overall size of the polymers (Pérez, Ribotta, Steffolani, \& Le, 2008), resulting in reduced E' values during the temperature gradient (Zhou, Liu, \& Tang, 2018).

\section{Rubisco sub-units participate in the network by means of both non-covalent and covalent bonds in wheat dough}

Analysis of SE-HPLC profiles in control and rubisco-enriched dough led us to conclude that rubisco triggers the formation of large polymers stabilised by disulphide bonds. Rubisco subunits are involved in these large polymers by covalent bonding, sometimes stabilised by disulphide bridges.

The high concentration of free thiols in rubisco may partially explain rubisco's ability to form disulphide bonds when used to enrich wheat dough. Indeed, it has been suggested that free thiols enhance the formation of disulphide bond dynamics in the gluten network (Auvergne et al., 2008). It is known that an increase in temperature above $50^{\circ} \mathrm{C}$ increases the size of glutenin polymers (Bloksma, 1972). Up to $70^{\circ} \mathrm{C}$, this increase in size is explained by sulfhydryldisulphide interchange (Schofield, Bottomley, Timms, \& Booth, 1983). These interchanges are explained by radical and nucleophilic mechanisms (Auvergne et al., 2008). It has been assumed that nucleophilic mechanisms increase in the presence of thiolate groups in equilibrium with thiol functions. In that sense, incorporating rubisco could enhance the interchange of disulphide bonds by providing free thiol groups in the system. To validate this mechanism, controlled alkylation experiments should be performed on rubisco before it is incorporated in the dough. Rubisco's participation in sulfhydryl-disulphide interchanges with gluten proteins would imply it is a coprotein network.

Besides covalent interactions, non-covalent bonds play a significant role in the mechanical properties of the gluten network (Belton, 1999; Belton et al., 1995; Shewry, Popineau, Lafiandra, \& Belton, 2001; Tkachuk \& Hlynka, 1968). The balance between the amino acid residues involved in hydrogen bonds with water molecules and inter-chain hydrogen bonds would lead to the formation of a "loops and trains" structure. The deformation and relaxation capacity of these structures would provide the elasticity to gluten molecules (Belton, 1999). Moreover, recent structural models of gluten suggest that weak interactions act as junction points that initiate the formation of the gluten network during hydration and mixing. Such weak bond nodes allow gluten polymers to percolate and to form a network (Dahesh, Banc, Duri, Morel, \& Ramos, 2016; Létang, Piau, \& Verdier, 1999; Ng, McKinley, \& Ewoldt, 2011). In our study, rubisco subunits were not leached out by water. Most were recovered in the gluten-like fraction and 


\section{Funding sources}

572 This work was supported by the Institut national de la recherche agronomique (National Institute of Agricultural

eluted at their expected molecular weight. This suggests that rubisco subunits establish weak bonds with wheat protein during dough mixing before any thermal treatment. Electrostatic interactions are unlikely because gluten proteins are weakly charged. Hydrophobic and hydrogen interactions control rubisco heat gelation in dispersed systems (Libouga, Aguié-Béghin, \& Douillard, 1996; Martin et al., 2014). The contribution of both hydrophobic and hydrogen interactions in rubisco reactivity in wheat dough during mixing can be assumed.

The formation of a co-protein network between gluten proteins and rubisco is the most likely hypothesis to explain our results concerning the interactions established by rubisco during mixing and heating and the properties of the resulting dough. This hypothesis is supported by protein network microstructure visualised by CLSM since rubisco and gluten are co-located in the network before thermal treatment. However, further investigations are needed to prove that rubisco and gluten interact specifically with each other.

\section{Conclusions}

The study of the mechanical properties and protein interactions of rubisco-enriched wheat dough clearly highlights its potential ability to increase the plant protein content of cereal-based foods. Rubisco behaviour is quite different from that of legume or even gluten proteins. Enrichment in pea proteins or gluten does not modify protein polymerisation even after thermal treatment. The thermo-mechanical properties of these pea or gluten-enriched doughs appear to be affected probably due to a modification of the distribution of water in the system, thereby limiting starch gelatinisation. The behaviour of rubisco is very different. Interestingly, rubisco protein is able to preserve the increase in elasticity of the dough during heating thanks to its own reactivity and to possible low competition with starch for water. Remarkably, hydrated and mixed with wheat semolina, rubisco formed both weak and disulphide bridges. It then joined the water-insoluble protein network. The concentration of large covalently linked polymers increased considerably during dough thermal treatment, because of the ability of rubisco to form new aggregates in these conditions. The colocation of gluten and rubisco proteins on micrographs supports the hypothesis that they even formed a co-protein network. To confirm the benefits of using rubisco to enrich cereal based food, it would be useful to test the mechanical properties of rubisco-wheat matrices at high deformations to better investigate the effect of protein enrichment on the rheological properties of the new food system in comparison to the better-known pea protein-enriched wheat matrices.

\section{Acknowledgments}

This study was conducted in the framework of the EU funded GreenProtein BBI-JU project (Grant Agreement No 720728). La Semoulerie de Bellevue is gratefully acknowledged for providing the durum wheat semolina. The authors would like to thank Joëlle Bonicel (IATE, INRAE), Bruno Novales (BIA, BIBS platform, INRAE), Juliette Le Goff (BIA, INRAE) and Valérie Beaumal (BIA, INRAE) for their help in performing SE-HPLC analyses, confocal microscopy training, DMTA analysis and confocal microscopy experiments, respectively. Guy Della Valle and Denis Lourdin are acknowledged for fruitful discussions.

Research) in the framework of the EU funded GreenProtein BBI-JU project (Grant Agreement No 720728).

\section{Competing interest statement}

None 


\section{References}

Aiking, H. (2014). Protein production: plant, profit, plus people ? American Journal of Clinical Nutrition, 100(3), 483-489. https://doi.org/10.3945/ajcn.113.071209.1

Auger, F., Morel, M. H., Dewilde, M., \& Redl, A. (2009). Mixing history affects gluten protein recovery, purity, and glutenin re-assembly capacity from optimally developed flour-water batters. Journal of Cereal Science, 49(3), 405-412. https://doi.org/10.1016/j.jcs.2009.01.008

Auvergne, R., Morel, M.-H., Menut, P., Giani, O., Guilbert, S., \& Robien, J.-J. (2008). Reactivity of Wheat Gluten Protein during Mechanical Mixing : Radical and Nucleophilic Reactions for the Addition of Molecules of Sulfur. Biomacromolecules, 9, 664-671.

Bahnassay, Y., \& Khan, K. (1986). Fortification of spaghetti with edible legumes. II. Rheological, processing, and quality evaluation studies. Cereal Chemistry, 63(3), 216-219.

Bahnassey, Y., Khan, K., \& Harrold, R. (1986). Fortification of Spaghetti with Edible Legumes. I. Physiochemical, Antinutritional, Amino Acid, and Mineral Composition. Cereal Chemistry, 63(3), 210-215.

Barbeau, W. E., \& Kinsella, J. E. (1988). Ribulose bisphosphate carboxylase/oxygenase (rubisco) from green leaves - potential as a food protein. Food Reviews International, 4(1), 93-127. https://doi.org/10.1080/87559128809540823

Belton, P. S. (1999). On the elasticity of wheat gluten. Journal of Cereal Science, 29(2), 103-107.

Belton, P. S., Colquhoun, I. J., Field, J. M., Grant, A., Shewry, P. R., Tatham, A. S., \& Wellner, N. (1995). FTIR and NMR studies on the hydration of a high Mr subunit of glutenin. International Journal of Biological Macromolecules, 17(2), 74-80. https://doi.org/10.1002/aic.690450902

Bloksma, A. H. (1972). The Relation Between the Thiol and Disulfide Contents of Dough and its Rheological Properties. Cereal Chemistry, 49, 104-118.

Bloksma, A. H. (1990). Rheology of the breadmaking process. Cereal Foods World, 35(2), 228-236.

Boukid, F., Zannini, E., Carini, E., \& Vittadini, E. (2019). Pulses for bread fortification: A necessity or a choice? Trends in Food Science and Technology, 88(June 2018), 416-428. https://doi.org/10.1016/j.tifs.2019.04.007

Bravo-Núñez, Á., Garzón, R., Rosell, C. M., \& Gómez, M. (2019). Evaluation of Starch-Protein Interactions as a Function of pH. Foods, 8(155), 1-10. https://doi.org/10.3390/foods8050155

Croy, R. R., Gatehouse, J. A., Tyler, M., \& Boulter, D. (1980). The purification and characterization of a third storage protein (convicilin) from the seeds of pea (Pisum sativum L.). The Biochemical Journal, 191(2), 509-516. https://doi.org/10.1042/bj1910509

Croy, R. R., Hoque, M. S., Gatehouse, J. A., \& Boulter, D. (1984). The major albumin proteins from pea (Pisum sativum L). Purification and some properties. The Biochemical Journal, 218(3), 795-803. https://doi.org/10.1042/bj2180795

Dahesh, M., Banc, A., Duri, A., Morel, M.-H., \& Ramos, L. (2016). Spontaneous gelation of wheat gluten proteins in a food grade solvent. Food Hydrocolloids, 52, 1-10. https://doi.org/10.1016/j.foodhyd.2015.06.014

Douillard, R. (1985). Propriétés biochimiques et physicochimiques des protéines des feuilles. In B. Gordon (Ed.), Protéines végétales (pp. 211-244). Lavoisier, Paris, FRA.

Dreese, P. C., Faubion, J. M., \& Hoseney, R. C. (1988). Dynamic rheological Properties of flour, Gluten, and Gluten-Starch Doughs. I. Tempretaure-Dependant Changes During Heating. Cereal Chemistry, 65(4), 348-353.

Edwards, N. M., Dexter, J. E., Scanlon, M. G., \& Cenkowski, S. (1999). Relationship of creep-recovery and dynamic oscillatory measurements to durum wheat physical dough properties. Cereal Chemistry, 76(5), 638-645. https://doi.org/10.1094/CCHEM.1999.76.5.638

Edwards, R. H., Miller, R. E., de Fremery, D., Knuckles, B. E., Bickoff, E. M., \& Kohler, G. O. (1975). Pilot Plant Production of an Edible White Fraction Leaf Protein Concentrate from Alfalfa. Journal of Agricultural and Food Chemistry, 23(4), 620-626. https://doi.org/10.1021/jf60200a046

Ellis, R. J. (1979). The most abundant protein in the world. Trends in Biochemical Sciences, 4(11), 241244. https://doi.org/10.1016/0968-0004(79)90212-3

Ellman, G. L. (1959). Tissue Sulfhydryl Groups. Archives of Biochemistry and Biophysics, 82, 70-77.

Felix, M., Perez-Puyana, V., Romero, A., \& Guerrero, A. (2017). Development of thermally processed bioactive pea protein gels: Evaluation of mechanical and antioxidant properties. Food and 
Bioproducts Processing, 101, 74-83. https://doi.org/10.1016/j.fbp.2016.10.013

Fiorentini, R., \& Galoppini, C. (1983). The proteins from leaves. Qualitas Plantarum Plant Foods for Human Nutrition, 32(3-4), 335-350. https://doi.org/10.1007/BF01091193

Firdaous, L., Fertin, B., Khelissa, O., Dhainaut, M., Nedjar, N., Chataigné, G., ... Dhulster, P. (2017). Adsorptive removal of polyphenols from an alfalfa white proteins concentrate: Adsorbent screening, adsorption kinetics and equilibrium study. Separation and Purification Technology, 178, 29-39. https://doi.org/10.1016/j.seppur.2017.01.009

Friel, S., Dangour, A. D., Garnett, T., Lock, K., Chalabi, Z., Roberts, I., ... Haines, A. (2009). Public health benefits of strategies to reduce greenhouse-gas emissions: food and agriculture. The Lancet, 374(9706), 2016-2025. https://doi.org/10.1016/S0140-6736(09)61753-0

Gatehouse, J. A., Gilroy, J., Hoque, M. S., \& Croy, R. R. (1985). Purification, properties and amino acid sequence of a low-Mr abundant seed protein from pea (Pisum sativum L.). The Biochemical Journal, 225(1), 239-247. https://doi.org/10.1042/bj2250239

Gatehouse, John A., Croy, R. R. D., Morton, H., Tyler, M., \& Boulter, D. (1981). Characterisation and Subunit Structures of the Vicilin Storage Proteins of Pea (Pisum sativum L.). European Journal of Biochemistry, 118(3), 627-633. https://doi.org/10.1111/j.1432-1033.1981.tb05565.x

Gerloff, E. D., Lima, I. H., \& Stahmann, M. A. (1965). Leal Proteins as Foodstuffs - Amino Acid Composition of Leaf Protein Concentrates. Journal of Agricultural and Food Chemistry, 13(2), 139-143. https://doi.org/10.1021/jf60138a012

Hadidi, M., Ibarz, A., Conde, J., \& Pagan, J. (2019). Optimisation of steam blanching on enzymatic activity, color and protein degradation of alfalfa (Medicago sativa) to improve some quality characteristics of its edible protein. Food Chemistry, 276(June 2018), 591-598. https://doi.org/10.1016/j.foodchem.2018.10.049

Hibberd, G. E. (1970). Dynamic viscoelastic behaviour of wheat flour doughs - Part II: Effects of water content in the linear region. Rheologica Acta, 9(4), 497-500. https://doi.org/10.1007/BF01985458

Hood, L. L., Cheng, S. G., Koch, U., \& Brunner, J. R. (1981). Alfalfa Proteins: Isolation and Partial Characterization of the Major Component - Fraction I Protein. Journal of Food Science, 46(6), 1843-1850. https://doi.org/10.1111/j.1365-2621.1981.tb04501.x

ING Economics department. (2017). The protein shift : will Europeans change their diet ?

Jekle, M., \& Becker, T. (2011). Dough microstructure: Novel analysis by quantification using confocal laser scanning microscopy. Food Research International, 44(4), 984-991. https://doi.org/10.1016/j.foodres.2011.02.036

Jekle, Mario, Mühlberger, K., \& Becker, T. (2016a). Starch-gluten interactions during gelatinization and its functionality in dough like model systems. Food Hydrocolloids, 54, 196-201. https://doi.org/10.1016/j.foodhyd.2015.10.005

Jekle, Mario, Mühlberger, K., \& Becker, T. (2016b). Starch-gluten interactions during gelatinization and its functionality in dough like model systems. Food Hydrocolloids, 54, 196-201. https://doi.org/10.1016/j.foodhyd.2015.10.005

John Reynolds, C., David Buckley, J., Weinstein, P., \& Boland, J. (2014). Are the dietary guidelines for meat, fat, fruit and vegetable consumption appropriate for environmental sustainability? A review of the literature. Nutrients, 6(6), 2251-2265. https://doi.org/10.3390/nu6062251

Khan, K., Huckle, L., \& Freeman, T. (1994). Disaggregation of Glutenin with Low Concentrations of Reducing Agent and with Sonication: Solubility, Electrophoretic, and Scanning Electron Microscopy Studies. Cereal Chemistry, 71(3), 242-247.

Kiskini, A., Vissers, A., Vincken, J. P., Gruppen, H., \& Wierenga, P. A. (2016). Effect of Plant Age on the Quantity and Quality of Proteins Extracted from Sugar Beet (Beta vulgaris L.) Leaves. Journal of Agricultural and Food Chemistry, 64(44), 8305-8314. https://doi.org/10.1021/acs.jafc.6b03095

Knuckles, B. E., Bickoff, E. M., \& Kohler, G. O. (1972). Pro-Xan Process: Methods for Increasing Protein Recovery from Alfalfa. Journal of Agricultural and Food Chemistry, 20(5), 1055-1057. https://doi.org/10.1021/jf60183a020

Knuckles, B. E., De Fremery, D., Bickoff, E. M., \& Kohler, G. O. (1975). Soluble Protein from Alfalfa Juice by Membrane Filtration. Journal of Agricultural and Food Chemistry, 23(2), 209-212. https://doi.org/10.1021/jf60198a030 
Knuckles, B. E., \& Kohler, G. O. (1982). Functional properties of edible protein concentrates from alfalfa. Journal of Agricultural and Food Chemistry, 30(4), 748-752. https://doi.org/10.1021/jf00112a030

Kristiawan, M., Micard, V., Maladira, P., Alchamieh, C., Maigret, J. E., Réguerre, A. L., ... Della Valle, G. (2018). Multi-scale structural changes of starch and proteins during pea flour extrusion. Food Research International, 108(January), 203-215. https://doi.org/10.1016/j.foodres.2018.03.027

Laleg, K., Barron, C., Cordelle, S., Schlich, P., Walrand, S., \& Micard, V. (2017). How the structure, nutritional and sensory attributes of pasta made from legume flour is affected by the proportion of legume protein. LWT - Food Science and Technology, 79, 471-478. https://doi.org/10.1016/j.Iwt.2017.01.069

Lefebvre, J. (2006). An outline of the non-linear viscoelastic behaviour of wheat flour dough in shear. Rheologica Acta, 45(4), 525-538. https://doi.org/10.1007/s00397-006-0093-3

Létang, C., Piau, M., \& Verdier, C. (1999). Characterization of wheat flour - water doughs . Part I : Rheometry and microstructure. Journal of Food Engineering, 41, 121-132. https://doi.org/10.1016/S0260-8774(99)00082-5

Lexander, K., Carlsson, R., Schalén, V., Simonsson, Å., \& Lundborg, T. (1970). Quantities and qualities of leaf protein concentrates from wild species and crop species grown under controlled conditions. Annals of Applied Biology, 66(2), 193-216. https://doi.org/10.1111/j.1744-7348.1970.tb06426.x

Libouga, D. G., Aguié-Béghin, V., \& Douillard, R. (1996). Thermal denaturation and gelation of rubisco: Effects of $\mathrm{pH}$ and ions. International Journal of Biological Macromolecules, 19(4), 271-277. https://doi.org/10.1016/S0141-8130(96)01137-3

Martin, A. H., Castellani, O., de Jong, G. A. H., Bovetto, L., \& Schmitt, C. (2019). Comparison of the functional properties of RuBisCO protein isolate extracted from sugar beet leaves with commercial whey protein and soy protein isolates. Journal of the Science of Food and Agriculture, 99(4), 1568-1576. https://doi.org/10.1002/jsfa.9335

Martin, A. H., Nieuwland, M., \& De Jong, G. A. H. (2014). Characterization of heat-set gels from RuBisCO in comparison to those from other proteins. Journal of Agricultural and Food Chemistry, 62, 10783-10791. https://doi.org/10.1021/jf502905g

Matta, N. K., Gatehouse, J. A., \& Boulter, D. (1981). Molecular and subunit heterogeneity of legumin of Pisum sativum L. (garden pea)- a multi-dimensional gel electrophoretic study. Journal of Experimental Botany, 32(6), 1295-1307. https://doi.org/10.1093/jxb/32.6.1295

McCann, T. H., \& Day, L. (2013). Effect of sodium chloride on gluten network formation, dough microstructure and rheology in relation to breadmaking. Journal of Cereal Science, 57(3), 444452. https://doi.org/10.1016/j.jcs.2013.01.011

Monnet, A. F., Laleg, K., Michon, C., \& Micard, V. (2019). Legume enriched cereal products: A generic approach derived from material science to predict their structuring by the process and their final properties. Trends in Food Science and Technology, 86(February), 131-143. https://doi.org/10.1016/j.tifs.2019.02.027

Morel, M. H., Bonicel, J., Micard, V., \& Guilbert, S. (2000). Protein Insolubilization and Thiol Oxidation in Sulfite-Treated Wheat Gluten Films during Aging at Various Temperatures and Relative Humidities. Journal of Agricultural and Food Chemistry, 48(2), 186-192.

Morel, M. H., Dehlon, P., Autran, J. C., Leygue, J. P., \& Bar-L'Helgouac'H, C. (2000). Effects of temperature, sonication time, and power settings on size distribution and extractability of total wheat flour proteins as determined by size-exclusion high-performance liquid chromatography. Cereal Chemistry, 77(5), 685-691. https://doi.org/10.1094/CCHEM.2000.77.5.685

Ng, T. S. K., McKinley, G. H., \& Ewoldt, R. H. (2011). Large amplitude oscillatory shear flow of gluten dough: A model power-law gel. Journal of Rheology, 55(3), 627-654. https://doi.org/10.1122/1.3570340

O'Kane, F. E., Vereijken, J. M., Gruppen, H., \& van Boekel, M. A. J. S. (2005). Food Chemistry and Toxicology Gelation Behavior of Protein Isolates Extracted from 5 Cultivars of Pisum sativum L . Journal of Food Science, 70(2), 132-137. https://doi.org/10.1111/j.1365-2621.2005.tb07073.x

Pérez, G., Ribotta, P. D., Steffolani, E., \& Le, A. E. (2008). Effect of soybean proteins on gluten depolymerization during mixing and. Journal of the Science of Food and Agriculture, 88, 455-463. https://doi.org/10.1002/jsfa 
Peters, J. P. C. M., Vergeldt, F. J., Boom, R. M., \& van der Goot, A. J. (2017). Water-binding capacity of protein-rich particles and their pellets. Food Hydrocolloids, 65, 144-156. https://doi.org/10.1016/j.foodhyd.2016.11.015

Petitot, M., Boyer, L., Minier, C., \& Micard, V. (2010). Fortification of pasta with split pea and faba bean flours: Pasta processing and quality evaluation. Food Research International, 43(2), 634-641. https://doi.org/10.1016/j.foodres.2009.07.020

Redl, A., Morel, M. H., Bonicel, J., Vergnes, B., \& Guilbert, S. (1999). Extrusion of wheat gluten plasticized with glycerol: Influence of process conditions on flow behavior, rheological properties, and molecular size distribution. Cereal Chemistry, 76(3), 361-370. https://doi.org/10.1094/CCHEM.1999.76.3.361

Ribotta, P. D., León, A. E., Pérez, G. T., \& Añón, M. C. (2005). Electrophoresis studies for determining wheat-soy protein interactions in dough and bread. European Food Research and Technology, 221(1-2), 48-53. https://doi.org/10.1007/s00217-005-1135-2

Rintamaki, E. (1989). Formation of disulphide cross-linked aggregates of large subunit from higher plant ribulose-1, 5-Bisphosphate carboxylase-oxygenase. Journal of Experimental Botany, 40(12), 1305-1313. https://doi.org/10.1093/jxb/40.12.1305

Rouillé, J., Chiron, H., Colonna, P., Della Valle, G., \& Lourdin, D. (2010). Dough/crumb transition during French bread baking. Journal of Cereal Science, 52(2), 161-169. https://doi.org/10.1016/j.jcs.2010.04.008

Schofield, J. D., Bottomley, R. C., Timms, M. F., \& Booth, M. R. (1983). The effect of heat on wheat gluten and the involvement of sulphydryl-disulphide interchange reactions. Journal of Cereal Science, 1(4), 241-253. https://doi.org/10.1016/S0733-5210(83)80012-5

Sheen, S. J., \& Sheen, V. L. (1985). Functional Properties of Fraction 1 Protein from Tobacco Leaf. Journal of Agricultural and Food Chemistry, 33(1), 79-83. https://doi.org/10.1021/jf00061a023

Shehzad, A., Chiron, H., Valle, G. Della, Lamrini, B., \& Lourdin, D. (2012). Energetical and rheological approaches of wheat flour dough mixing with a spiral mixer. Journal of Food Engineering, 110(1), 60-70. https://doi.org/10.1016/j.jfoodeng.2011.12.008

Shewry, P. R., Popineau, Y., Lafiandra, D., \& Belton, P. (2001). Wheat glutenin subunits and dough elasticity: Findings of the EUROWHEAT project. Trends in Food Science and Technology, 11(12), 433-441. https://doi.org/10.1016/S0924-2244(01)00035-8

Tamayo Tenorio, A., Gieteling, J., De Jong, G. A. H., Boom, R. M., \& Van Der Goot, A. J. (2016). Recovery of protein from green leaves: Overview of crucial steps for utilisation. Food Chemistry, 203, 402408. https://doi.org/10.1016/j.foodchem.2016.02.092

Tkachuk, R., \& Hlynka, I. (1968). Some properties of dough and gluten in D2O. Cereal Chemistry, 45, 80-87.

Udenigwe, C. C., Okolie, C. L., Qian, H., Ohanenye, I. C., Agyei, D., \& Aluko, R. E. (2017). Ribulose-1,5bisphosphate carboxylase as a sustainable and promising plant source of bioactive peptides for food applications. Trends in Food Science and Technology, 69, 74-82. https://doi.org/10.1016/j.tifs.2017.09.001

Van Lun, M., Van Der Spoel, D., \& Andersson, I. (2011). Subunit interface dynamics in hexadecameric Rubisco. Journal of Molecular Biology, 411(5), 1083-1098. https://doi.org/10.1016/j.jmb.2011.06.052

Vanin, F. M., Michon, C., \& Lucas, T. (2013). Effect of the drying rate on the complex viscosity of wheat flour dough transforming into crust and crumb during baking. Journal of Cereal Science, 58(2), 290-297. https://doi.org/10.1016/j.jcs.2013.06.003

Veraverbeke, W. S., \& Delcour, J. A. (2002). Wheat protein composition and properties of wheat glutenin in relation to breadmaking functionality. Critical Reviews in Food Science and Nutrition, 42(3), 179-208. https://doi.org/10.1080/10408690290825510

Wang, K. Q., Luo, S. Z., Zhong, X. Y., Cai, J., Jiang, S. T., \& Zheng, Z. (2017). Changes in chemical interactions and protein conformation during heat-induced wheat gluten gel formation. Food Chemistry, 214, 393-399. https://doi.org/10.1016/j.foodchem.2016.07.037

Wild, F., Czerny, M., Janssen, A. M., Kole, A. P. W., Zunabovic, M., \& Domig, K. J. (2014). The evolution of a plant-based alternative to meat. Agro Food Industry Hi Tech, 25(February), 45-49.

Willett, W., Rockström, J., Loken, B., Springmann, M., Lang, T., Vermeulen, S., ... Murray, C. J. L. (2019). 
Food in the Anthropocene: the EAT-Lancet Commission on healthy diets from sustainable food systems. The Lancet, 393(10170), 447-492. https://doi.org/10.1016/S0140-6736(18)31788-4

Zanoletti, M., Marti, A., Marengo, M., lametti, S., Pagani, M. A., \& Renzetti, S. (2017). Understanding the influence of buckwheat bran on wheat dough baking performance: Mechanistic insights from molecular and material science approaches. Food Research International, 102(September), 728737. https://doi.org/10.1016/j.foodres.2017.09.052

Zhou, J., Liu, J., \& Tang, X. (2018). Effects of whey and soy protein addition on bread rheological property of wheat flour. Journal of Texture Studies, 49(1), 38-46.

https://doi.org/10.1111/jtxs.12275

802 


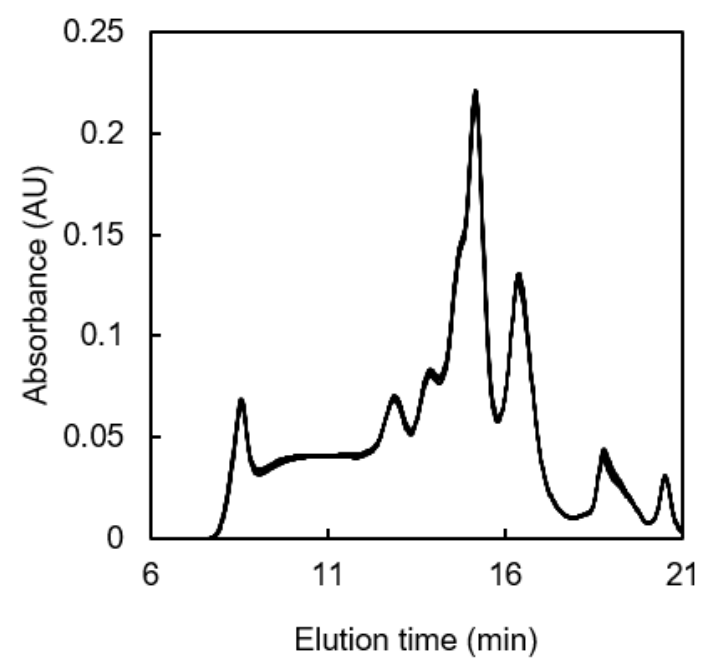

804

805

806

807

808

Supplementary fig. 1 Comparison of three SE-HPLC elution profiles of SDS soluble proteins extracted from the same sample and two chromatograms extracted from another sample in exactly same conditions (16.3\% rubiscoenriched dough, $48.2 \%$ water wb).

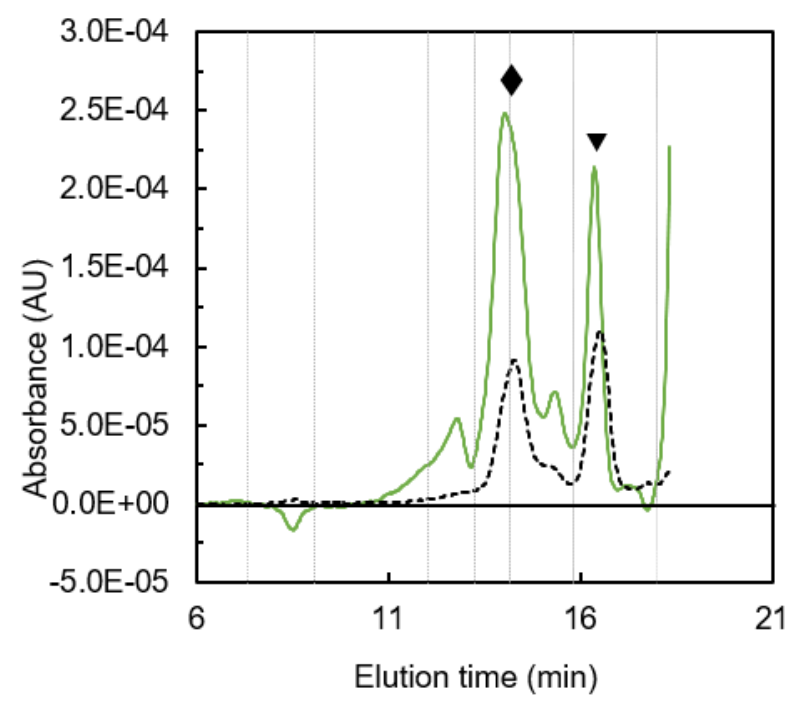

Supplementary fig. 2 Differential SE-HPLC profile (solid line) of SDS+DTE soluble proteins from a $37.4 \%$ rubiscoenriched raw dough compared to the profile of rubisco protein concentrate (dotted line) adjusted to the same rubisco weight. Differential profiles were obtained by subtracting the SE-HPLC profiles of SDS+DTE soluble proteins of wheat control raw dough from the profile of rubisco-enriched raw dough (both adjusted to same semolina weight). For the sake of readability, the elution profile is represented only up to 18 minutes. Symbols represent rubisco subunits: small chain (SC: $\nabla$ ) and large chain (LC: $\diamond$ ). 


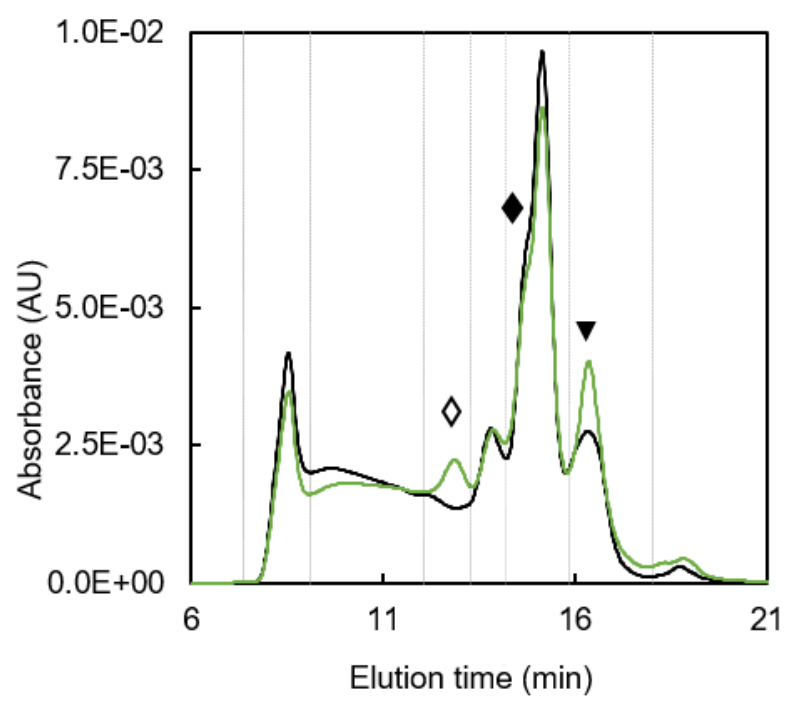

816

Supplementary fig. 3 Experimental SE-HPLC profiles (solid lines) of SDS soluble proteins of gluten-like fraction extracted from raw control doughs (black line) and 37.4\% rubisco-enriched dough (green line). Symbols represent rubisco subunits: small chain (SC; $\boldsymbol{\nabla})$, large chain (LC; $)$ and large chain dimer (LC dimer; $\diamond)$. Elution profiles after normalisation on the basis of $1 \mathrm{mg}$ of total protein in the sample. 